Illinois State University

ISU ReD: Research and eData

Faculty Publications - Finance, Insurance, and

Law

Finance, Insurance, and Law

2016

\title{
Mutual Funds' Soft Dollar Arrangements: Determinants, Impact on Shareholder Wealth, and Relation to Governance
}

Yaman Ö. Erzurumlu

Doğuş University

Vladimir Kotomin

Illinois State University, vkotomi@ilstu.edu

Follow this and additional works at: https://ir.library.illinoisstate.edu/fpfil

Part of the Finance and Financial Management Commons

\section{Recommended Citation}

Erzurumlu, Yaman Ö. and Kotomin, Vladimir, "Mutual Funds' Soft Dollar Arrangements: Determinants, Impact on Shareholder Wealth, and Relation to Governance" (2016). Faculty Publications - Finance, Insurance, and Law. 5.

https://ir.library.illinoisstate.edu/fpfil/5

This Article is brought to you for free and open access by the Finance, Insurance, and Law at ISU ReD: Research and eData. It has been accepted for inclusion in Faculty Publications - Finance, Insurance, and Law by an authorized administrator of ISU ReD: Research and eData. For more information, please contact ISUReD@ilstu.edu. 


\title{
Mutual Funds' Soft Dollar Arrangements: Determinants, Impact on Shareholder Wealth, and Relation to Governance
}

\author{
Yaman Ö. Erzurumlu \\ Bahçeşehir University, İstanbul, Turkey \\ Vladimir Kotomin \\ Illinois State University, Normal, IL, USA
}

\begin{abstract}
Mutual fund advisers either expense the cost of research and other services or pay for them with soft dollars. This study is the first to use actual soft dollar and total brokerage commission figures for a large number of funds and to examine how soft dollars are linked to mutual fund governance. Employing a survivorship bias-free sample of actively managed US mutual funds, we find that higher soft dollar and total brokerage commissions are associated with higher advisory fees but not with higher risk-adjusted fund returns. These findings suggest that mutual fund shareholders, on average, do not benefit from the research and the information supplied by third parties such as brokers. We also find that larger and more highly compensated boards are associated with lower advisory fees. Larger boards are also associated with slightly lower turnover. The median tenure of board directors is negatively correlated with soft dollar commissions and turnover, but not correlated with total brokerage commissions or the cost of turning over a portfolio. Higher proportions of directors with a finance background are associated with higher advisory fees, brokerage commissions, and turnover costs. These associations might indicate greater agency costs.
\end{abstract}

Keywords Mutual funds $\bullet$ Soft dollars $\bullet$ Mutual fund fees $\bullet$ Mutual fund performance $\bullet$ Mutual fund governance

JEL classification $\mathrm{G} 20 \cdot \mathrm{G} 23 \cdot \mathrm{G} 34$ 


\section{Introduction}

Investing in financial assets via intermediaries such as mutual funds can provide investors with the diversification they want. But, because the mutual fund shareholders are assessed an annual expense ratio for the professional management of their portfolios, this diversification can be costly. Further, funds can also charge separate sales or distribution charges (front- and back-end loads, $12 \mathrm{~b}-1$ fees). These costs are disclosed prominently in the funds' prospectuses and their reports to the shareholders. In addition, the shareholders pay the cost of brokerage commissions incurred by the fund; commissions are a major category of expenses but are not part of the reported expense ratio. ${ }^{1}$

The legal fiduciary duty of the mutual funds' advisers as defined by the Securities and Exchange Commission (SEC) includes but is not limited to the requirement to seek the best transaction execution. In addition to execution, the brokers can provide other services to the funds' advisers, such as the sales of the funds' shares, investment research and statistical information, and administrative services. Funds can produce these services in-house or pay third parties outright, thus including their cost in the expense ratio. Alternatively, the funds can pay brokers for these services by bundling the costs with the execution commissions and then deducting these bundled commissions directly from the fund's assets, which bypasses the expense ratio. Section 28(e) of the Securities Exchange Act of 1934 allows a "safe harbor" that

\footnotetext{
${ }^{1}$ The Securities and Exchange Commission's Report on mutual fund fees and expenses (2000) explains it as the absence of a widely accepted approach to measure spread costs. Including trade commissions in the expense ratio can be misleading if brokers charging higher commissions have better execution that results in lower spread costs.
} 
permits advisers to transfer a premium to brokers for these additional services. This section also requires advisers to disclose such arrangements. The disclosure of these bundled soft dollar commissions is more opaque than expensing the cost of non-execution services. Edelen et al. (2012) argue that the lack of visibility of soft dollar commissions can exacerbate agency conflicts and result in less efficient fund operations. They suggest that funds engage in the opaque disclosure of costs because such disclosures are associated with a less negative impact on their flows. The SEC's Guidance Regarding Client Commission Practices under Section 28(e) of the Securities Exchange Act of 1934 (2006) states:

Use of client commissions to pay for research and brokerage services presents money managers with significant conflicts of interest, and may give incentives for managers to disregard their best execution obligations when directing orders to obtain client commission services as well as to trade client securities inappropriately in order to earn credits for client commission services.

The funds' managers can trade excessively to generate a target volume of commission payments that reduces the efficiency of operations (Edelen et al. 2012). The opaqueness of soft dollar arrangements makes them hard to monitor not only by the shareholders but also by the boards, which potentially leads to governance inefficiencies.

Purchasing additional services with soft dollars can result in two benefits to the fund's shareholders: (i) higher risk-adjusted returns on their portfolios as a result of the obtained research and information, and (ii) lower advisory fees because the cost of research and other additional services that otherwise would be part of the total expense ratio is part of the brokerage commissions. Not consistently achieving at least one of these benefits indicates that the soft dollar arrangements, on average, lead to a reduction in the shareholders' wealth. 
Numerous studies examine the performance of mutual funds (e.g., Carhart 1997; Chen et al. 2004; Daniel et al. 1997) and their expenses, fees, and contracts (e.g., Bergstresser et al. 2009; Deli 2002; Gao and Livingston 2008; Livingston and O’Neal 1996; Kuhnen 2009; Luo 2002). Relatively few studies directly examine the determinants and the use of soft dollars by mutual funds (e.g., Conrad et al. 2001; Edelen et al. 2012; Livingston and O’Neal 1996), probably due to lack of soft dollar data or the difficulty in retrieving such data.

We examine the relations between the use of soft dollar arrangements and (i) the fund, contract environment, and the brokers' participation characteristics; (ii) the funds' governance (characteristics of the funds' boards); and (iii) the potential benefits to shareholders. We use hand-collected soft dollar and total brokerage commission data to create a survivorship bias-free sample of 391 actively managed US-based equity mutual funds from 1999 through 2003 . To our knowledge, this study is the first one that uses actual (not estimated) soft dollar commission amounts at the fund level for a large number of mutual funds and that examines soft dollar use in the context of mutual fund governance.

We find that the use of soft dollars varies widely across funds. This variation implies that using actual soft dollar amounts is likely to increase the robustness of the results. We find that funds with higher soft dollar commissions do not have better risk-adjusted performance but charge higher advisory fees. Therefore, fund shareholders, on average, do not benefit from soft dollar arrangements. The funds with larger and more highly compensated boards tend to have lower advisory fees. The boards with a longer median tenure of directors are associated with lower soft dollar fees and slightly lower turnover. A proportion of directors with a finance 
background on the fund's board is positively correlated with total brokerage commissions and the cost of turning over a portfolio.

This paper proceeds as follows. Section 2 highlights the use and disclosure of soft dollar arrangements by mutual funds. In Section 3, we discuss the potential impact of soft dollar arrangements on the shareholders' wealth and the potential determinants of soft dollar use. In Section 4, we describe the data and methods. We report and discuss the empirical results in Section 5. Section 6 is the conclusion.

\section{Soft dollar use and disclosure by mutual funds}

The use of soft dollars is common if not an industry norm. Greenwich Associates reported in 1996 that $71 \%$ of the total transaction executions involved some form of soft dollar arrangement (Wirth 1997). Livingston and O’Neal (1996) suggest that a substantial amount of brokerage commissions are payments for research services rather than for execution. Goldstein et al. (2009) suggest that the persistence of high per-share trade commissions in an era of increased competition from discount brokers reflects the bundling of premium services rather than specific characteristics of the trade. The SEC (1998) estimates that soft dollar commissions for research products add up to $30-50 \%$ of the total brokerage expenses, reaching approximately $\$ 1.4$ billion in 1998. Conrad et al. (2001) estimate that an average proportion of the soft dollar commissions paid for research is $60 \%$. Our initial screening of equity mutual funds discloses that two thirds of the funds report the adoption of soft dollar arrangements. 
Because a fund's shareholders ultimately pay the brokerage fees, critics argue that soft dollars represent a breach of loyalty in which the fund's advisers unjustly enrich themselves by shifting the research bill to investors. Practitioners (e.g., Ambachtsheer 1993; Blume 1993; Bogle 2009) generally have a negative opinion of soft dollar practices. Bogle (2009) considers the use of soft dollars for marketing a waste of the shareholders' assets. Blume (1993) finds that soft dollar arrangements often lead institutional managers to use brokers that they ordinarily would not use. On the other hand, Horan and Johnsen (2008) hypothesize that by paying the adviser's research bill up-front, the broker posts a quality-assuring performance bond that efficiently subsidizes the adviser's investment research. ${ }^{2}$ Also, Johnsen (2009) argues that soft dollars are an innovative and efficient form of economic organization that benefits the funds' investors.

The SEC requires mutual funds to supply investors with the fund's prospectus and on request, the Statement of Additional Information (SAI). The prospectus reports the total expense ratio (which does not include brokerage commissions), front-end and back-end loads, and 12b-1 fees (while they are part of the expense ratio, they also must be reported separately). The SAI reports brokerage commissions. The existence of soft dollar commissions, but not their amount, must be disclosed. There is no specific format for disclosure. When disclosed, a typical statement on the soft dollar commissions and related transactions reads as follows: "For the fiscal year

\footnotetext{
${ }^{2}$ This is because, according to Horan and Johnsen (2008), an institutional broker typically provides a fund's manager with credits up-front to pay a specific dollar amount of the manager's research bill to independent vendors. In exchange, the manager promises to send the broker a specific amount of future trades at premium commission rates.
} 
ended June 30, 2002, the Funds directed the following amount of transactions and paid the following brokerage commissions to brokers who provided research services in connection with such transactions." For unsophisticated investors, the effect of brokerage commissions and turnover on the net asset value (NAV) and returns might not be clear. Barber et al. (2005) show that investors pay more attention to more "visible" or up-front fees such as front-end loads than to the funds' operating expenses. The SAI might be hard to obtain (Gao and Livingstone 2008), and in most cases the information on soft dollar commissions is not disclosed clearly and prominently. The funds also supply N-SAR reports to the SEC on a semiannual basis. The format of the N-SAR reports, which contain large amounts of information, is not retail investor friendly. The Carlin (2009) model suggests that funds might have an incentive to decrease the transparency of payments and induce complexity because it prevents some retail consumers from obtaining knowledge about market prices. The SEC (1998) reports that many advisors do not provide sufficient information to enable investors to understand their soft dollar policies and practices.

Our sample period ends in 2003; it is fairly old. However, there appears to be little need for an update since not much has changed in the funds' brokerage expenses and soft dollar practices between then and now. ${ }^{3}$ A report by Woodbine Associates (2012) finds that the practice of bundling commissions remains deeply ingrained in the industry despite the investors' calls for

\footnotetext{
${ }^{3}$ Firms are rarely punished by regulators for abusing soft dollar practices. The most recent occurrence is an $\$ 813,000$ fine imposed by the SEC on a New York-based firm Instinet on December 26, 2013 for inappropriate use of soft dollars (SEC 2013).
} 
transparency and cost savings. M. Samelson, the author of the report, is critical of the practice and states in his discussion of the report:

Abolishing soft dollar arrangements would lead to a far more efficient and transparent environment and remove many conflicts of interest between money managers and their clients. It would also likely lead to immediate changes in business practices and industry structure.

\section{Soft dollars: potential determinants and impact on shareholder wealth}

\subsection{Potential benefits of soft dollars to shareholders}

If additional services and research help improve portfolio management, we should observe a positive relation between soft dollar commissions and the funds' performance. The information obtained through soft dollar arrangements is less likely to be embedded in the prices of traders that do not have that information. The informed investors might profit more from their information if less of it is incorporated into the prices by uninformed investors (Livne and Trueman 2002). Hence, the fund might be motivated to trade more. Moreover, Brennan and Chordia (1993) argue that high-quality information can also result in higher revenue to the broker as the seller of the information. However, the quality of research and other services obtained under soft dollar arrangements is not necessarily homogeneous, so the impact of soft dollar use is likely to vary across brokers. Brennan and Chordia (1993) suggest that the amount of trading done by the information purchaser could be a proxy for the quality of information. Thus, advisers that obtain what they believe is high quality information might engage in more transactions per dollar of soft commissions and achieve better gross performance. On the other hand, Edelen et al. (2012) suggest that funds might engage in excessive (superfluous) trading to 
generate the target level of commission payments, thus wasting shareholders' money. In this case, higher soft dollar commissions would be associated with higher turnover and poorer performance.

The second potential benefit of soft dollar arrangements to the shareholders is lower advisory fees because the cost of research is paid as part of the brokerage commissions instead. However, Livingston and O’Neal (1996) find no trade-off between aggregate brokerage commissions per trade and the total expense ratio and suggest that the funds' shareholders do not benefit from soft dollar arrangements through a reduction in advisory fees. Therefore, higher soft dollar commissions are not necessarily associated with lower advisory fees. A negative (positive or no) relation between soft dollar commissions and advisory fees would indicate that the shareholders do (do not) benefit from a decrease in advisory fees as the soft dollar commissions increase.

Deli (2002) finds that the advisory fee is directly related to the fund's turnover and inversely related to the fund's size and the adviser's size. In addition, to capture the effect of competition between different investment objectives, we control for the concentration of assets within each objective.

\subsection{Potential determinants of soft dollar arrangements}

\subsubsection{Considerations for the broker's selection}

The management of brokerage services starts with the determination of the broker's participation. If choosing brokers is a strategic decision, then the use of soft dollars should reflect 
the adviser's ex ante considerations on the participation. The mutual funds in the United States disclose which of the following services they consider when selecting brokers: (1) sales of the fund's shares, (2) receipt of investment research and statistical information, (3) receipt of quotations for portfolio valuations, (4) ability to execute portfolio transactions to obtain the best price and execution, and (5) receipt of telephone line and wire services.

These five services fall into four categories: (1) distribution, (2) research, (3 and 5) administrative, and (4) transaction execution. A broker's service that is selected mostly "to obtain the best price and execution" should be associated with lower brokerage commissions and less soft dollar use. However, almost all of the funds in our sample report it as one of the considerations for the broker's participation. This finding is not surprising because obtaining the best execution for clients is part of the fiduciary duty of investment companies. We hypothesize that the soft dollar use should be higher if the "receipt of investment research and statistical information" is a consideration for the broker's selection. Further, the adviser might choose brokers based on their ability to market the fund's shares. ${ }^{4}$

\subsubsection{Brokers and contract environment characteristics}

Concentration of the brokers. The fewer brokers the fund uses, the more concentrated the supply of brokerage services. Goldstein et al. (2009) show that brokerage commission patterns are consistent with long-term agreements between the funds' advisers and brokers, where an adviser

\footnotetext{
${ }^{4}$ A SEC ruling in December 2004 prohibited the use of commission bundling to pay for distribution expenditures. Our sample ends in 2003. Funds are still allowed to charge 12b-1 fees for distribution. The $12 \mathrm{~b}-1$ fee is part of a fund's expense ratio but it is also reported separately.
} 
directs a target level of order flow to a broker as payment for premium services such as research and share distribution. Thus, if the adviser chooses brokers for their premium services, a more concentrated supply of services would be associated with higher commissions. If, on the other hand, the adviser chooses brokers to minimize the cost of brokerage services, a more concentrated supply of services would be associated with lower total brokerage commissions.

Institutional relations with the brokers. The general fiduciary duty is imposed on investment advisers by Section 206 of the Investment Adviser Act. An investment adviser should use an affiliated broker only if the broker can provide the best execution. In addition to the commissions for transaction executions and soft dollar arrangements, the funds can transfer rent to brokers as part of the sales loads and $12 \mathrm{~b}-1$ fees, especially if the broker is part of their sales force. If these rent transfers exist, the broker can provide transaction execution and additional services at lower costs. Christoffersen et al. (2013) find that a fund's future performance decreases as the brokers' payments from the load increase, especially for unaffiliated brokers. A reverse rent transfer takes place when the broker has an arrangement to return or credit part of the commissions or profits back to the fund's adviser. This reverse rent transfer might induce the adviser to use more soft dollars. We control in our tests for the broker's affiliation, the sales loads and 12b-1 fees received by the brokers, and the arrangements to credit part of the commissions or profits back to the adviser. 


\subsubsection{Fund and board characteristics}

Size, turnover, and investment objectives. First, larger funds obtain lower commissions as a percent of total assets because the fixed component of commissions is spread over a larger amount of assets. Second, higher turnover could be a sign of aggressive trading, possibly induced by the information paid for by the soft dollars. Third, the funds with certain investment objectives might be more likely to demand or rely on external research. For example, Livingston and O’Neal (1996) suggest that international funds have higher brokerage expenses because they invest in stocks that are relatively difficult to research. We use investment objective fixed effects in our regressions to control for these differences.

Fund Governance. The decision to use soft dollar arrangements are made by the fund's adviser and are overseen by the board. Hypothetically, soft dollar arrangements should be evaluated by the fund's board based on two criteria. First, are they associated with improved risk-adjusted performance? Second, does the advisory fee decrease proportionally to the cost of the outsourced management services? Gil-Bazo and Ruiz-Verdu (2009) suggest that better governance might bring fees more in line with the performance. However, it is fairly common for advisers to supply poorly detailed information regarding the types of services obtained with soft dollars (SEC 1998). The opaqueness of soft dollar arrangements can increase the complexity of the board's task.

There is a great deal of literature that studies the relations between the mutual funds' expenses and governance. The evidence regarding the board's size and governance is mixed. 
Tufano and Sevick (1997) suggest that funds with larger boards have higher total fees. They also argue that more independent boards are better watchdogs. Baker and Gompers (2003) and Kuhnen (2009) suggest that larger boards have higher monitoring potential. Moreover, the characteristics of individual board members can affect the board's governing abilities. These characteristics (e.g., background, independence, outside directorships, or compensation) are not necessarily independent because new board members emerge from the pool of candidates nominated by current board members.

The relation between the board members' tenure and fund governance is not obvious a priori. On the one hand, the funds can benefit from the experience of members who have been on the board for a long time. On the other hand, the selection process could be influenced by the adviser. Xie et al. (2003) suggest that independent directors with finance backgrounds are better monitors of earnings management. Having an outside directorship could be interpreted as a signal of high quality in the directors (Booth and Deli 1999; Shivdasani and Yermack 1999). If a director collects income from other directorships, it might reduce the probability of aligning the director's and the adviser's interests through increased compensation. The literature provides mixed evidence about the effect of compensation on the oversight of independent directors. A positive relation between compensation and advisory fees could signal the superior abilities of directors that deserve higher compensation, but it also could be an attempt to create an incentive to align the independent directors' interests with the adviser's. ${ }^{5}$

\footnotetext{
${ }^{5}$ See Tufano and Sevick (1997), Vafeas (1999), Perry (2000), Ryan and Wiggins (2004).
} 


\section{Data and methodology}

For the period from 1999 through 2003, we randomly select 432 actively managed equity, convertible, or balanced funds from the CRSP Survivor-Bias-Free US Mutual Fund Database that report using soft dollars in at least one year during the study period. ${ }^{6,7}$ After excluding Vanguard funds and apparent errors, the sample is reduced to 391 funds from 70 families that are managed by over 120 different advisers. ${ }^{8}$ Many of these funds are very small. Accordingly, we run empirical tests on all of the funds in the sample as well as on the funds with total net assets in excess of $\$ 50$ million (304 funds).

This sample is representative of the US equity mutual fund universe during the study period. The CRSP database averaged around 4,000 funds in the objectives that we are examining. The database averaged 542 families per year from 1999 to 2003, and the total net assets of all of the funds (non-index equity, convertible, and balanced funds) averaged $\$ 6.06$ trillion ( $\$ 2.76$ trillion) per year in that period. Our sample covers around $10 \%$ of both the funds and the net assets of the total funds. ${ }^{9}$ The average advisory fee of the total mutual funds was

\footnotetext{
${ }^{6}$ It is possible that the advisers who are more successful at using the services obtained through the soft dollar arrangements are more likely to disclose amounts of bundled commissions in addition to their existence. To determine whether the lack of uniform disclosure leads to selection bias, we conduct the Heckman sample selection bias test at the initial screening stage with 106 funds, 31 of which do not disclose the information. The test fails to reject the null of no selection bias and is robust to treating the funds that report zero soft dollar commissions as having no soft dollar arrangements. Including them into the sample under the assumption that they do not use soft dollar arrangements does not qualitatively affect the results.

${ }^{7}$ When we exclude convertible and balanced funds from the analyses, the results are qualitatively the same.

${ }^{8}$ Vanguard funds did not use soft dollars for research and other services during the sample period.

${ }^{9}$ The CRSP Mutual Fund Database tracked share classes but not funds before 2004. According to the 2013 Investment Company Institute Fact Book (2013), there were an average of 4,471 actively managed equity funds per
} 
about 74 basis points, compared to 78 basis points in our sample. The proportions of funds in each investment objective and the proportion of dead funds in the sample match those in the CRSP Mutual Fund Database.

Some of the variables are reported at the share-class level (e.g., total net assets, loads and 12b-1 fees, returns) while others (e.g., advisory fee, commissions, and turnover) are at the fund level. ${ }^{10}$ Thus, we need to aggregate the former to the fund level. We do this aggregation by applying the shares' class weights based on each class's total net assets at the beginning of a year (a month for the variables reported monthly, such as returns and total net assets). The year 1999 was picked as the first year because less than a half of the randomly selected funds disclosed the amounts of soft dollar commissions prior to 1999. The sample includes 40 fund-years in which zero soft dollar commissions are explicitly reported. ${ }^{11,12}$

The information about soft dollar commissions, total brokerage commissions, and board members is collected from the funds' SAIs. The rest of the data are collected from the funds' NSARs.

year from 1999 to 2003 (4,966 including hybrid funds), with average net assets of \$791 million (\$788 million including hybrid funds). The average net assets per fund is $\$ 724$ million in our sample.

${ }^{10}$ The advisory fee often has a "stacked" structure: e.g., the advisory fee may be $1 \%$ for the first $\$ 10 \mathrm{mln}$ of assets under management, $0.75 \%$ for the next $\$ 90 \mathrm{mln}$ in assets (between $\$ 10$ million and $\$ 100$ million), and $0.5 \%$ for assets above $\$ 100 \mathrm{mln}$. In such cases we compute the advisory fee based on the total net assets at the beginning of the year. In this example, if these assets were $\$ 200$ million at the beginning of the year, the weighted advisory fee is $(10 \mathrm{mln} * 0.01+90 \mathrm{mln} * 0.0075+\$ 100 \mathrm{mln} * 0.005) / 200 \mathrm{mln}$, or $0.638 \%$.

${ }^{11}$ Excluding these 40 zero soft dollar fund-years from the sample does not change the results.

${ }^{12}$ Large fund families such as Fidelity are likely to appear more frequently in the sample set. However, because a fund's family with a higher weight in the industry is more likely to influence the industry norms, this characteristic of a sample is representative of the whole population of actively managed equity mutual funds. 
Livingston and O'Neal (1996) note that sells are likely to be higher than buys at times of high redemptions. Likewise, buys are likely to exceed sells at times of asset inflows. Therefore, the net turnover reported in Form N-SAR understates the total assets traded. We calculate the turnover as the sum of the purchases and sales reported in the N-SAR divided by the fund's weighted average assets over a year. ${ }^{13}$

Advisers report the total amount of brokerage commissions as well as the amounts paid to the top ten brokers. We estimate the broker concentration by computing the non-normalized Herfindahl index of the brokerage commissions paid by the fund's management to the top ten brokers. Two major alternative rent transfers to brokers and dealers are front-end loads and 12b1 fees. Not all front-end loads and 12b-1 fees are received by the brokers. We use the actual amounts paid to brokers. Further, we include the fund's and the board's characteristics that we discussed in the previous section to shed light on the role the funds' boards play in soft dollar arrangements. The literature mostly suggests that larger boards and longer tenured members are better watchdogs.

We start by studying the link between the different measures of the investing costs and the fund's performance by running the following unbalanced panel regression with White's

\footnotetext{
${ }^{13}$ Funds with high turnover also bear the market impact cost of transactions in addition to brokerage commissions. However, Berkowitz et al. (1988) argue that the market impact costs are small relative to commissions and conclude that there is no economic trade-off between the market impact costs and commissions. Chan and Lakonishok (1993) suggest no correlation between the market impact costs and brokerage commissions. Thus, following Livingston and O’Neal's (1996), we do not control for the market impact cost.
} 
period standard errors and covariance and Wallace and Hussain's estimator of component variances:

$$
\text { FFAR }_{i, t}=\beta_{0}+\beta_{1} \operatorname{Cost}_{i, t}+\beta_{2} \operatorname{Ln}\left(\text { FundSize }_{i, t-1}\right)+\varepsilon_{i, t}
$$

The FFAR (the four-factor adjusted return) is the annualized alpha from the estimation of the Carhart (1997) four-factor model for each fund-year by using 12 monthly observations. The Carhart model captures the fund's before-fees risk-adjusted return. ${ }^{14}$ The Cost is represented by one of the following variables that measure the trading costs of the investors:

(i) soft dollar use $(S D U)=$ soft dollar commissions divided by the total brokerage commissions for fund $i$ in year $t$, in \%;

(ii) soft dollar fee $($ SoftFee $)=$ soft dollar commissions divided by net weighted average assets of fund $i$ in year $t$, in basis points;

(iii) brokerage fee $(\mathrm{BrkFee})=$ total brokerage commissions divided by net weighted average assets of the fund for fund $i$ in year $t$, in basis points;

(iv) turnover (Turn) computed as the sum of purchases and sales divided by net weighted average assets; or

(v) brokerage commissions for turning over the fund portfolio once (TurnCost) computed as BrkFee divided by Turn, in basis points.

\footnotetext{
${ }^{14}$ If a fund has multiple share classes, a weighted average monthly return is computed based on the weights of different share classes at the beginning of each month.
} 
The FundSize is the average of the 12 monthly net asset figures in thousands of dollars. We include TurnCost following Carhart (1997). We lag the log of the fund's size one year to avoid a spurious correlation. The objective and the year fixed effects are included. ${ }^{15,16}$

To investigate whether shareholders benefit from a reduction in advisory fees when soft dollars or other direct or indirect investing costs increase, we use the following model:

$$
\begin{aligned}
\text { AdvFee }_{i, t} & =\beta_{0}+\beta_{1} \text { Cost }_{i, t}+\beta_{2} \operatorname{Ln}\left(\text { FundSize }_{i, t}\right)+\beta_{3} \operatorname{Ln}\left(\text { AdvSize }_{i, t}\right)+\beta_{4} \operatorname{Ln}_{\left(\text {Accts }_{i, t}\right)} \\
& +\beta_{5} \text { Reimb }_{i, t}+\beta_{6} \text { ObjConcntr }_{i, t}+\beta_{7} \text { Indep }_{i, t}+\beta_{8} \text { Seats }_{i, t}+\beta_{9 \text { MedTenure }_{i, t}}+\beta_{10 \text { Fin }_{i, t}} \\
& +\beta_{11} \text { OtherDir }_{i, t}+\beta_{12} \text { Compens }_{i, t-1}+\varepsilon_{i, t}
\end{aligned}
$$

Along with the variables defined previously, we add the following:

$$
\begin{aligned}
& A d v F_{e e} e_{, t}=\text { dollar amount of gross advisory fee paid by fund } i \text { in year } t \text { divided by the } \\
& \text { weighted average assets of fund } i \text { in year } t \text {, in basis points; } \\
& A d v \text { Size }_{i, t}=\text { adviser's size, measured as the total assets of funds in the CRSP database } \\
& \text { managed by the same adviser, in millions of dollars; } \\
& \text { Accts }_{i, t}=\text { number of shareholder accounts with the fund; } \\
& \operatorname{Reimb}_{i, t}=\text { dollar amount of the (partial) reimbursement of expenses by the fund's adviser } \\
& \text { to shareholders divided by the fund's total size (total net assets), in basis points; }
\end{aligned}
$$

\footnotetext{
${ }^{15} \mathrm{We}$ also ran the regression with the variable SoftPerTr, ${ }_{i, t}$, defined as the log of the ratio of the dollar amount of transactions involving soft dollars to the soft dollar commissions - a control for the quality of information suggested by Brennan and Chordia (1993). A higher ratio might be suggestive of better information. This variables' estimated coefficient is not significant, and its inclusion does not affect the results qualitatively. However, including it results in "losing" 104 funds that do not report the amount of transactions involving soft dollars. Accordingly, we do not use this variable.

${ }^{16}$ Including family fixed effects for all 70 families would dramatically reduce the regression's power, especially given that we already use the objective and year fixed effects (some families are represented by one or very few funds in our sample). When we add dummy variables for the 11 most highly represented families (accounting for 191 funds, about a half of our sample), the results do not change notably. Therefore, we do not include family fixed effects in the final set of regressions.
} 


$$
\begin{aligned}
& \text { ObjConcntr }_{i, t}=\text { normalized Herfindahl index of the fund's objective calculated following } \\
& \text { Indep }_{i, t} \quad=\text { percentage of board directors considered independent; } \\
& \text { Seats }, \text { }=\text { number of seats on the board of directors; } \\
& \text { MedTenure }_{i, t}=\text { median tenure of the board's directors; } \\
& \text { Fin }_{i, t}=\text { percentage of directors with finance backgrounds; } \\
& \text { OtherDir }{ }_{i, t}=\text { percentage of directors with other directorships; }
\end{aligned}
$$

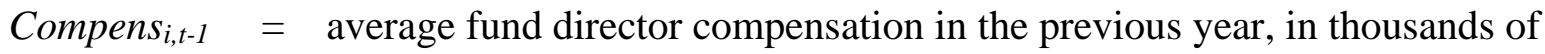

The model includes the standard fund-specific control variables of the adviser's and the fund's sizes, as well as the governance variables that the literature suggests are related to the advisory fees, such as the board's size and independence. We also control for (i) the number of accounts because the administrative cost is a significant portion of the advisory fee, (ii) the reimbursement rate because the ex post reimbursements might imply ex ante higher advisory fees, and (iii) the objective concentration as a proxy for competition within the fund's objective. We add the boards' characteristics to test if and how governance is related to the advisory fees. ${ }^{18,19}$ The year and objective fixed effects are included.

\footnotetext{
${ }^{17}$ The normalized Herfindahl index characterizes the relative competitiveness in an investment objective to which the fund belongs compared to the case where net assets are equally distributed among all funds within the objective. We repeat the tests without normalizing the Herfindahl index; the results are qualitatively the same.

${ }^{18}$ To be classified as a director with a finance background, one either must have had a finance occupation in the past or is currently occupied in the finance industry (the latter group constitutes the majority of such directors). Since directors often sit on the boards of many funds offered by the same sponsor, the variable OtherDir only considers directorships outside of the fund's sponsor (in our sample, all of them also happen to be outside of the mutual fund industry). The variable constructed in this manner captures the proportion of directors who do not depend only on one source of fees and potentially sends a signal about the board's quality.

${ }^{19}$ Tufano and Sevick (1997) suggest measures of excess director compensation. When we use excess compensation (either per seat or per director, following Tufano and Sevick's (1997) Equations 1 and 2 on p.338 in their paper) in place of unadjusted compensation, it is not significant in the regressions. Perhaps directors are concerned more
} 
Further, we test the links between the costs of investing and the characteristics of the funds, the contracting environment, and the governance by estimating the following regression:

$$
\begin{aligned}
& \text { Cost }_{i, t}=\beta_{0}+\beta_{1} \text { Research }_{i, t}+\beta_{2} \text { Sales }_{i, t}+\beta_{3} \text { AltComp }_{i, t}+\beta_{4} \text { BrConcntr }_{i, t}+\beta_{5} \text { Aff }_{i, t}+\beta_{6} \text { Cred }_{i, t} \\
& +\beta_{7} \operatorname{Ln}\left(\text { FundSize }_{i, t}\right)+\beta_{8} \operatorname{Ln}\left(\text { AdvSize }_{i, t}\right)+\beta_{9} \operatorname{Ln}\left(\text { Accts }_{i, t}\right)+\beta_{10} \text { Reimb }_{i, t}+\beta_{11} \text { ObjConcntr }_{i, t} \\
& +\beta_{12} \text { Turn }_{i, t}+\beta_{13} \text { Indep }_{i, t}+\beta_{14 \text { Seats }_{i, t}}+\beta_{15 \text { MedTenure }} \text { Met }_{16}+\beta_{16} \text { Fin }_{i, t} \\
& +\beta_{17} \text { OtherDir }_{i, t}+\beta_{18} \text { Compens }_{i, t-1}+\varepsilon_{i, t}
\end{aligned}
$$

Along with the variables defined previously, we add the following:

Research $_{i, t}=$ one if the receipt of investment research and statistical information is a consideration for the broker's participation;

Sales $_{i, t}=$ one if the sale of the fund's shares is a consideration for the broker's participation;

AltCompi,t $=$ the proportion of total weighted assets received by the brokers or dealers as part of the total front-end load and $12 \mathrm{~b}-1$ fee, in basis points $;{ }^{20}$

BrConctr $_{i, t}=$ the fund's brokerage service concentration measured by the Herfindahl index;

$A f f_{i, t} \quad=$ one if any broker or dealer is affiliated with the adviser;

Cred $_{i, t}=$ one if there is an arrangement to return or credit part of the total commissions or profits by at least one broker to the fund's adviser.

This model also includes the objective and year fixed effects. For the regressions analyses, we winsorize all of the non-indicator variables except Fin and Reimb, which do not have much variation in the tails, at the $1 \%$ and $99 \%$ levels.

about the potential loss of income from the fund's sponsor (in case they oppose the fund's policies and lose their seat) than how this income compares to the fees paid by other funds or sponsors.

${ }^{20}$ Decomposing alternative rent transfers into loads and $12 \mathrm{~b}-1$ fees does not affect the results. 


\section{Empirical results}

5.1 Univariate and bivariate analyses

Table 1 reports the descriptive statistics. On average, $45 \%$ of the total brokerage commissions are paid under soft dollar arrangements. This figure is consistent with the SEC's (1998) estimate of soft dollar use. The total brokerage commissions are on average 41.9 basis points $(0.42 \%)$ of a fund's total assets of which 18.6 basis points are transferred as soft dollar commissions. For the subsample that excludes the smallest funds, the total and soft dollar commissions are 34.4 and 17.7 basis points respectively. Both soft dollar use and commissions vary widely around the means. Thus, a fund with the mean size of $\$ 724$ million in our sample transfers around $\$ 1.35$ million per year to its brokers under soft dollar arrangements ( $\$ 1.73$ million for the subsample of the larger funds, or $0.177 \%$ of $\$ 979$ million). The average advisory fee is 78 basis points. The average turnover is $313 \%$ (244\%) for all of the funds (the larger funds). On average, $75 \%$ of the board directors are considered independent, with the directors' median tenure at six years. About a quarter of the directors have finance backgrounds, and $60 \%$ have at least one other directorship.

[Insert Table 1 about here]

In $88.6 \%$ of the fund-years in our sample, the funds report that the receipt of investment research and statistical information influences their choice of brokers. In $32.2 \%$ of the fundyears, the funds consider the sales of their shares in determining the broker's participation. An affiliated broker or dealer is considered in $28.7 \%$ of the fund-years. In $29.8 \%$ of the fund-years, 
an arrangement with at least one broker to return part of the commissions to the adviser is considered.

Table 2 reports the correlations between the measure of performance (FFAR - the fourfactor model alpha) and the variables that in one way or another measure the investing costs of mutual funds (total and soft dollar commissions, soft dollar use, advisory fees, turnover, and turnover costs). We observe that larger funds tend to perform better and have lower commissions: the turnover and the investing costs (SoftFee, BrkFee, TurnCost, AdvFee) are negatively correlated with size and performance but the proportion of soft dollars in the commission structure $(S D U)$ is weakly and positively correlated with size and performance. These correlations suggest that mutual fund shareholders, on average, do not benefit from soft dollar arrangements in the form of higher returns or lower advisory fees.

[Insert Table 2 about here]

Table 3 provides a more detailed look into the relations between the same seven variables by sorting the fund-years with respect to each variable one at a time and reporting the means of the highest and lowest deciles for each variable. There are few differences between Panels A and B, so we refer mostly to Panel A.

The first three rows inside the table compare the means for each variable corresponding to the fund-years in the bottom (first) and top (tenth) FFAR deciles. The fund-years in the bottom FFAR decile have a mean of $-25.4 \%$ versus $26.5 \%$ for the top decile, with the difference being statistically significant at the $1 \%$ level. Further, we observe that the fund-years in the lowest 
FFAR decile have the highest average SoftFee of $40.1 \mathrm{bps}$ (the decile rank is ten), and the fundyears in the highest FFAR decile have the second highest average SoftFee of 26.7 bps (the decile rank is nine). The rest of the FFAR decile comparison shows that the fund-years with the best risk-adjusted performance are associated with fairly high total brokerage fees (the decile rank is 8), highest $S D U$ (10), average size (5), above average turnover (7), and advisory fees (6).

When we rank the fund-years by SoftFee (the second three rows in the table), we observe that the lowest SoftFee decile is associated with the best adjusted performance $(F F A R)$. The FFAR difference from the highest SoftFee decile is significant at the $1 \%$ level when the smallest funds are excluded (Panel B) but only marginally significant when all of the funds are retained (Panel A). The combination of the results reported in the first six rows of the table suggests that a minority of the funds in our sample are able to put soft dollars to good use and receive superior research from brokers or third parties (or simply have good luck in some years), while most funds with high soft dollar commissions perform poorly on a risk-adjusted basis.

[Insert Table 3 about here]

In unreported tests, we reject the null hypothesis that the SoftFee does not Granger cause AdvFee (FFAR) at one, two, and three (one and two) lags.

\subsection{Regression analysis}

\subsubsection{Soft dollars and fund performance}

If services are acquired with soft dollars to improve the portfolio's performance, the shareholders might benefit from higher risk-adjusted returns. Table 4 reports the output of Equation (1) - the 
regressions of the alphas from the Carhart (1997) four-factor model on various measures of the investing costs of mutual funds and the control variables. ${ }^{21}$ The negative relation between SoftFee and the risk-adjusted performance suggests that the costs of the soft dollar arrangements exceed the benefits, and that the fund's shareholders bear these incremental costs. The SoftFee's estimated coefficient of -0.06 indicates that increasing the SoftFee by $0.01 \%$ ( 1 basis point, because SoftFee is in basis points) of total assets is associated with a $0.06 \%$ decline in the riskadjusted performance. However, because the $S D U$ is not significant and the BrkFee is, it appears that the bundling or unbundling of the commissions is not as important as the amount of commissions paid relative to the fund's size, turnover, and the turnover costs. This finding supports the studies that suggest that aggressive trading costs the shareholders more than it benefits them (e.g., Livingstone and O’Neal 1996).

[Insert Table 4 about here]

Our results suggest that most funds do not achieve persistent positive performance by using the information obtained through soft dollar arrangements, which is consistent with Conrad et al. (2001) and inconsistent with Horan and Johnsen (2008), who find that premium commissions that are paid by private money managers are positively related to the risk-adjusted performance. The additional costs associated with high turnover and the resulting high commissions, both bundled and unbundled, are not, on average, offset by better investment returns.

\footnotetext{
${ }^{21}$ Because we use the lag of the log of FundSize in Equation (1) to avoid a spurious correlation, the number of fundyears is reduced.
} 
When we use the CAPM's alphas instead of the four-factor model's alphas, the results are somewhat different. Among the key independent variables in the Table 4 regressions, the turnover is negative and significant for the regressions on the whole sample. The TurnCost is negative and significant for the sample of the larger funds, and the BrkFee is only marginally significant in both the entire sample and the subsample of the larger funds. Except for the size, all of the remaining coefficients are not significant. To test whether the bundled commissions are used more for advice on investing in securities loading up on the factors in the four-factor model, we examine the correlations between SoftFee and each of the factor betas. These correlations are low; the highest and the only statistically significant correlation coefficient is between SoftFee and the momentum beta at only 0.06 , with a p-value of 0.035 . Because the four-factor model remains the dominant one in the literature on the mutual funds' performance, we retain the alpha of the four-factor model as the dependent variable in Equation 1. Whether we use the fourfactor's or the market model's alphas, the relation between the excess risk-adjusted return and the soft dollars (or other measures of investing costs) is not positive, which indicates that the mutual funds' shareholders do not benefit from higher trade-related expenses.

\subsubsection{Soft dollars and advisory fees}

Table 5 shows the estimation outputs of Equation 2. The key result is that the higher soft dollar commissions, total brokerage commissions, and turnover are all associated with higher advisory fees. A ten basis point increase in the soft dollar commissions is associated with an advisory fee increase of 1.1 basis points. This result runs contrary to the idea that the shareholders who 
surrender part of their wealth to soft dollar commissions should benefit from a reduction in the advisory fees. ${ }^{22}$ We cannot rule out that the information provided by the outside source could have higher quality. Nevertheless, our previous results suggest that the cost of this information tends to outweigh its benefits, and a high level of soft dollar commissions is in general not beneficial to the funds' shareholders. The larger funds have lower advisory fees, while the funds with more accounts have higher fees, which is consistent with higher administrative costs.

Three of the governance variables are significantly correlated with advisory fees. The association between the board's size and the advisory fee is negative, which supports the findings of Baker and Gompers (2003) and Kuhnen (2009) and suggests that larger boards are better monitors. The boards with higher proportions of directors with finance backgrounds are associated with higher advisory fees, while more highly compensated boards are associated with lower advisory fees. ${ }^{23}$

[Insert Table 5 about here]

5.3 Determinants of soft dollar fees and other measures of the investing costs of mutual funds In this subsection, we analyze the output of the Equation 3 estimations, that is, the potential determinants of soft dollar use (SDU), soft dollar fees (SoftFee), brokerage fees (BrkFee), turnover (Turn), and the turnover cost (TurnCost), reported in Table 6. As before, we focus on

\footnotetext{
${ }^{22}$ The positive association between turnover and advisory fees is consistent with the findings of Deli (2002).

${ }^{23}$ Excluding the governance variables does not change the signs, magnitude, and significance of the remaining variables' coefficients.
} 
the results that hold consistently between Panel A (all funds) and Panel B (funds with net assets over $\$ 50 \mathrm{mln})$.

Among the variables for the broker's participation and contracting environment research, sales, alternative compensation (loads and 12b-1 fees), concentration, affiliation, and credit - only the research dummy is significant in both panels in one of the regressions: it is associated with a lower turnover. The larger funds tend to have lower total brokerage fees, soft dollar commissions, and turnover costs, likely because of economies of scale (consistent with Livingston and O’Neal 1996). Higher turnover is associated with higher total and soft dollar commissions (SoftFee and BrkFee) but not a higher share of soft dollars in the commission structure $(S D U)$.

When it comes to the fund's governance, the board's independence is associated with lower turnover costs and lower soft dollar commissions (marginally for the entire sample). The boards with higher median tenures of directors are associated with lower soft dollar commissions and turnover. Thus, the shareholders might benefit from the experience of the directors who have been on the fund's board for a longer period and are more familiar with the fund. The boards with a higher percentage of directors with finance backgrounds (Fin) are associated with higher cost measures (SoftFee, BrkFee, and TurnCost) but not with higher turnover. One possible explanation is that the presence of directors with finance backgrounds might exacerbate agency conflicts: the boards can have their interests aligned more with the interests of the managers than 
with the shareholders. ${ }^{24}$ More highly compensated boards are associated with higher soft dollar use and slightly lower turnover.

\section{[Insert Table 6 about here]}

Our governance results suggest that agency conflicts might be exacerbated and investors might be worse off when a significant proportion of the fund's directors have a finance background. Whether that is the case is a question we leave to future research.

\section{Conclusion}

The bundling of services under soft dollar arrangements could possibly benefit mutual funds' shareholders if it results in better risk-adjusted returns and/or lower advisory fees. On the other hand, it is possible that the shareholder wealth is reduced through the use of soft dollar arrangements. The results of our study tend to support the latter conjecture.

Our study is the first one to use actual hand-collected soft dollar and total brokerage commission figures for a large number of actively managed mutual funds. Controlling for a variety of factors, we find that higher soft dollar and total brokerage commissions are associated with lower risk-adjusted returns based on the four-factor model and the higher advisory fees of mutual funds. The bundling or unbundling of commissions is not as important as the amount of commissions paid relative to the fund's size, turnover, and the turnover costs. While it is possible

\footnotetext{
${ }^{24}$ In a recent study, Fricke (2014) reports that more highly compensated fund boards and boards with lower fund holdings are associated with lower turnover of underperforming funds' managers, consistent with the agency costs explanation.
} 
that research paid for by soft dollars is superior, its quality is likely not homogenous across providers, and its costs tend to outweigh its benefits to shareholders.

The second contribution of our study is in examining soft dollars and other measures of the investing costs of mutual funds in a governance context. The characteristics that the literature associates with higher quality boards do not seem to unambiguously benefit the mutual funds' shareholders. On the one hand, larger boards and more highly compensated boards are associated with lower advisory fees and brokerage commissions. In addition, boards with higher median tenure of directors are associated with lower soft dollar fees and turnover. On the other hand, more highly compensated boards are associated with higher soft dollar fees and boards with higher proportions of directors with finance backgrounds are associated with higher advisory fees, soft dollar commissions, and total brokerage commissions, as well as higher turnover costs for a portfolio. Therefore, it is possible that high proportions of directors with finance backgrounds on the funds' boards might exacerbate agency conflicts.

\section{Acknowledgements}

We thank Melissa Frye, David Nanigian, Abhishek Varma, Drew Winters, and the anonymous referee for helpful comments. All remaining errors are ours. 


\section{References}

Ambachtsheer K (1993) The soft dollar question: what is the answer? Financ Anal J 49(1):8-10

Baker M, Gompers PA (2003) The determinants of board structure at the initial public offering. J Law Econ 46:569-598

Barber B, Odean T, Zheng L (2005) Out of sight, out of mind: the effects of expenses on mutual fund flows. J Bus 78:2095-2119

Bergstresser D, Chalmers J, Tufano P (2009) Assessing the cost and benefit of brokers: a preliminary analysis of the mutual fund industry. Rev Financ Stud 22:4129 - 4156

Berkowitz S, Logue D, Noser E (1988) The total cost of transactions on the NYSE. J Financ 43:97-112

Blume M (1993) Soft dollars and the brokerage industry. Financ Anal J 49(2):36-44

Bogle J (2009) The end of “soft dollars”? Financ Anal J 65(2):48-53

Booth J, Deli D (1999) On executives of financial institutions as outside directors. J Corp Financ $5: 227-250$

Brennan M, Chordia T (1993) Brokerage commission schedules. J Financ 48:1379-1402

Carhart M 1(997) On persistence in mutual fund performance. J Financ 52:57-82

Carlin B (2009) Strategic price complexity in retail financial markets. J Financ Econ 91:278-287

Chan LKC, Lakonishok J (1993) Institutional trades and intraday stock price behavior. J Financ Econ 33:173-199

Chen J, Hong H, Huang M, Kubik J (2004) Does fund size erode mutual fund performance? The role of liquidity and organization. Am Econ Rev 94:1276-1302

Christoffersen S, Evans R, Musto D (2013) What do consumers' fund flows maximize? Evidence from their brokers' incentives. J Financ 68:201-235

Conrad J, Johnson K, Wahal S (2001) Institutional trading and soft dollars. J Financ 61:397-416

Daniel K, M Grinblatt, Titman S, Wermers R (1997) Measuring mutual fund performance with characteristic-based benchmarks. J Financ 52:1035- 1058

Deli D (2002) Mutual fund advisory contracts: an empirical investigation. J Financ 57:109-133

Edelen R, Evans R, Kadlec G (2012) Disclosure and agency conflict: evidence from mutual fund commission bundling. J Financ Econ 103:308-326

Fricke E (2014) Board holdings, compensation and mutual fund manager turnover. J Financ Serv Res. doi: 10.1007/s10693-014-0196-4

Gao X, Livingston M (2008) The components of mutual fund fees. Financ Mark Inst Instrum 17:197-223 
Gil-Bazo J, Ruiz-Verdu P (2009) The relation between price and performance in the mutual fund industry. J Financ 64:2153-2183

Goldstein M, Irvine P, Kandel E, Weiner Z (2009) Brokerage commissions and institutional trading patterns. Rev Financ Stud 22:5175-5212

Horan S, Johnsen DB (2008) Can third-party payments benefit the principal? The case of soft dollar brokerage. Int Rev Law Econ 28:56-77

Investment Company Institute (2013) 2013 Investment Company Institute Fact Book. http://www.ici.org/pdf/2013_factbook.pdf. Accessed 10 November 2014.

Johnsen DB (2009) The SEC's 2006 soft dollar guidance: law and economics. Cardozo Law Rev $30: 1545-1613$

Kuhnen C (2009) Social networks, corporate governance and contracting in the mutual fund industry. J Financ 64:2185-2220

Livingston M, O’Neal E (1996) Mutual fund brokerage commissions. J Financ Res 19:273-292

Livne G, Trueman B (2002) The impact of soft dollars on market equilibrium and investors' profits. University of Exeter and University of California, Los Angeles working paper, February

Luo GY (2002) Mutual fund fee-setting, market structure and mark-ups. Economica 69:245-271

Perry T (2000) Does the structure of board compensation matter? Evidence from CEO turnover. Arizona State University working paper, June

Ryan H, Wiggins R (2004) Who is in whose pocket? Director compensation, board independence, and barriers to effective monitoring. J Financ Econ 73:497-524

Securities and Exchange Commission (1998) Inspection report on the soft dollar practices of broker-dealers, investment advisers and mutual funds. http://www.sec.gov/news/studies/softdolr.htm. Accessed 13 July 2014

Securities and Exchange Commission (2000) Report on mutual fund fees and expenses. http://www.sec.gov/news/studies/feestudy.htm. Accessed 12 April 2014

Securities and Exchange Commission (2006) Guidance regarding client commission practices under Section 28(e) of the Securities Exchange Act of 1934. http://www.sec.gov/rules/interp/34-52635.pdf. Accessed 13 July 2014

Securities and Exchange Commission (2013) SEC charges New York-based brokerage firm for ignoring red flags in soft dollar scheme.

http://www.sec.gov/News/PressRelease/Detail/PressRelease/1370540557746\#.U8MUNB D5c3V. Accessed 13 July 2014

Shivdasani A, Yermack D (1999) CEO involvement in the selection of new board members: an empirical analysis. J Financ 54:1829-1854 
Tufano P, Sevick M (1997) Board structure and fee-setting in the U.S. mutual fund industry. J Financ Econ 46:321-355

Vafeas N (1999) Board meeting frequency and firm performance. J Financ Econ 53:113-142

Wirth G (1997) Greenwich: institutions are uncomfortable with their soft dollar arrangements. Investment Dealers Digest, June 9

Woodbine Associates (2012) Soft dollars and bundled services: practices, history, and controversy. http://tabbforum.com/opinions/soft-dollars-are-the-us-equity-markets-indenial (summary). Accessed 13 July 2014

Xie B, Davidson W, DaDalt P (2003) Earnings management and corporate governance: the role of the board and the audit committee. J Corp Financ 9:295-316 
Table 1 Descriptive Statistics. This table provides descriptive statistics for the variables employed in the study. The sample represents annual data from 1999 through 2003 for a random selection of actively managed funds from the CRSP Survivor-Bias-Free US Mutual Fund Database. The unit of observation is a fund-year.

\begin{tabular}{|c|c|c|c|c|c|c|c|c|c|}
\hline \multirow[b]{2}{*}{ Variable definition } & \multirow[b]{2}{*}{ Mnemonic } & \multicolumn{4}{|c|}{ All Funds (391 funds) } & \multicolumn{4}{|c|}{$\begin{array}{c}\text { Funds with Net Assets over } \\
\$ 50 \mathrm{mln} \text { (304 funds) }\end{array}$} \\
\hline & & $\mathrm{N}$ & Mean & Median & St. Dev. & $\mathrm{N}$ & Mean & Median & St. Dev. \\
\hline Four-factor Adjusted Return, \% & FFAR & 1,466 & -0.98 & -1.57 & 14.04 & 1,070 & -0.60 & -1.42 & 13.88 \\
\hline Soft \$ / Total Brokerage, \% & SDU & 1,571 & 44.9 & 33.4 & 36.8 & 1,152 & 46.6 & 35.2 & 37.4 \\
\hline Soft \$ / TNA, bps & SoftFee & 1,571 & 18.6 & 6.8 & 33.9 & 1,152 & 17.7 & 6.1 & 33.6 \\
\hline Brokerage Fee / TNA, bps & BrkFee & 1,571 & 41.9 & 22.8 & 57.6 & 1,152 & 34.4 & 20.3 & 44.9 \\
\hline Turnover & Turn & 1,566 & 3.13 & 2.03 & 4.80 & 1,150 & 2.44 & 1.87 & 2.38 \\
\hline Cost to turn over portfolio, bps & TurnCost & 1,566 & 16.1 & 12.7 & 22.1 & 1,150 & 14.9 & 12.4 & 15.33 \\
\hline Advisory Fee / TNA, bps & AdvFee & 1,565 & 78.0 & 75.5 & 31.4 & 1,147 & 76.3 & 73.0 & 32.1 \\
\hline Fund Size, \$ million & FundSize & 1,571 & 724 & 166 & 1,833 & 1,152 & 979 & 313 & 2,083 \\
\hline Adviser size, $\$$ million & AdvSize & 1,468 & 82,495 & 21,092 & 161,495 & 1,088 & 86,020 & 24,847 & 174,246 \\
\hline Number of accounts & Accts & 1,537 & 60,216 & 7,530 & 199,843 & 1,123 & 81,693 & 16,327 & 230,116 \\
\hline Reimbursement, $\%$ & Reimb & 1,562 & 19.2 & 1.2 & 70.2 & 1,143 & 6.0 & 0.3 & 19.7 \\
\hline Objective Concentration & ObjConcntr & 1,556 & 21.9 & 22.1 & 7.9 & 1,139 & 22.0 & 22.1 & 7.8 \\
\hline Number of board seats & Seats & 1,566 & 8.8 & 9.0 & 3.1 & 1,149 & 8.9 & 9.0 & 3.1 \\
\hline$\%$ of independent directors & Indep & 1,566 & 75.2 & 75.0 & 12.7 & 1,149 & 75.1 & 75.0 & 13.6 \\
\hline $\begin{array}{l}\text { Median tenure of directors, yrs. } \\
\% \text { of directors with finance }\end{array}$ & MedTenure & 1,566 & 6.3 & 6.0 & 4.1 & 1,149 & 6.7 & 6.0 & 4.2 \\
\hline $\begin{array}{l}\text { background } \\
\% \text { of directors with other }\end{array}$ & Fin & 1,566 & 23.5 & 20.0 & 18.9 & 1,149 & 22.6 & 18.0 & 19.6 \\
\hline directorships & OtherDir & 1,566 & 59.7 & 67.0 & 35.1 & 1,149 & 61.7 & 67.0 & 34.6 \\
\hline $\begin{array}{l}\text { Aggregate lagged director } \\
\text { compensation, } \$ 000 \mathrm{~s}\end{array}$ & Compens & 1,543 & 100.6 & 70.1 & 87.1 & 1,137 & 105.2 & 75.0 & 88.0 \\
\hline Front-end load $+12 b-1$, bps & AltComp & 1,521 & 15.9 & 0.0 & 50.3 & 1,110 & 16.3 & 0.6 & 49.4 \\
\hline Brokerage Herfindahl, \% & BrConcntr & 1,543 & 11.7 & 8.2 & 11.1 & 1,130 & 11.1 & 7.7 & 10.6 \\
\hline Research (dummy) & Research & 1,550 & 0.886 & & & 1,131 & 0.886 & & \\
\hline Sales of fund shares (dummy) & Sales & 1,549 & 0.322 & & & 1,131 & 0.349 & & \\
\hline Affiliated broker (dummy) & Aff & 1,554 & 0.287 & & & 1,136 & 0.289 & & \\
\hline $\begin{array}{l}\text { Arrangement to return } \\
\text { commissions (dummy) }\end{array}$ & Cred & 1,549 & 0.298 & & & 1,131 & 0.286 & & \\
\hline
\end{tabular}


Table 2 Correlations. This table presents correlations between key variables employed in the study. FFAR is the four-factor model alpha (stands for the four-factor adjusted return), in percent, SoftFee is the proportion of total net assets paid as bundled (soft dollar) commissions, in basis points, BrkFee is the proportion of total net assets paid as total brokerage commissions, in basis points, SDU is the ratio of soft dollar commissions to total brokerage commissions (SoftFee/BrkFee), in \%, Fund Size is the fund's total net assets in a given year (the average of the twelve monthly net asset figures), Turn is turnover (total sales and purchases divided by total net assets), in decimals, AdvFee is the gross advisory fee divided by total net assets, in basis points, and TurnCost is the cost of turning over the portfolio once (BrkFee/Turn), in basis points.

\begin{tabular}{|c|c|c|c|c|c|c|c|}
\hline \multicolumn{8}{|c|}{ Panel A: All Funds } \\
\hline & FFAR & SoftFee & BrkFee & SDU & Fund Size & Turn & AdvFee \\
\hline \multicolumn{8}{|l|}{ FFAR } \\
\hline SoftFee & $-0.08 * * *$ & & & & & & \\
\hline BrkFee & $-0.14 * * *$ & $0.64 * * *$ & & & & & \\
\hline SDU & $0.05^{*}$ & $0.47 * * *$ & -0.00 & & & & \\
\hline Fund Size & $0.07 * *$ & $-0.08 * * *$ & $-0.15 * * *$ & $0.09 * * *$ & & & \\
\hline Turn & $-0.07 * *$ & $0.24 * * *$ & $0.65 * * *$ & $-0.07 * * *$ & $-0.11 * * *$ & & \\
\hline AdvFee & $-0.06 * *$ & $0.18 * * *$ & $0.26 * * *$ & $-0.06^{* *}$ & $-0.19 * * *$ & $0.15 * * *$ & \\
\hline TurnCost & $-0.08 * * *$ & $0.16^{* * *}$ & $0.25 * * *$ & $-0.05 * *$ & $-0.08 * * *$ & $-0.08 * * *$ & -0.01 \\
\hline
\end{tabular}

Panel B: Funds with Net Assets over \$50mln

\begin{tabular}{llllllll}
\hline & FFAR & SoftFee & BrkFee & SDU & Fund Size & Turn & AdvFee \\
FFAR & & & & & & & \\
SoftFee & $-0.12 * * *$ & & & & & \\
BrkFee & $-0.22^{* * *}$ & $0.77 * * *$ & & & & \\
SDU & $0.05^{*}$ & $0.47 * * *$ & $0.09 * * *$ & & & \\
Fund Size & $0.07 * *$ & $-0.09 * * *$ & $-0.15 * * *$ & $0.09 * * *$ & & & \\
Turn & $-0.09 * * *$ & $0.39 * * *$ & $0.62 * * *$ & 0.02 & $-0.12 * * *$ & & \\
AdvFee & $-0.06 * *$ & $0.20 * * *$ & $0.32 * * *$ & $-0.06 * *$ & $-0.19 * * *$ & $0.22 * * *$ & \\
TurnCost & $-0.16^{* * *}$ & $0.24 * * *$ & $0.35 * * *$ & -0.01 & $-0.10^{* * *}$ & -0.05 & $-0.08 * * *$ \\
\hline
\end{tabular}

***, **, * denote significance at the $1 \%, 5 \%$, and $10 \%$ level, respectively. 
Table 3 Decile Means. This table presents the means of key variables corresponding to the lowest and highest deciles of each of these variables. Decile ranks are in parentheses next to the means. The diagonal is bolded because it represents decile means for the variables themselves, thus the decile ranks are always 1 and 10 on the diagonal. For example, in the left upper corner the mean FFAR is $-0.254(-25.4 \%)$ for the lowest FFAR decile and $0.265(26.5 \%)$ for the top decile. Moving to the right, the mean SoftFee for fund-years in the lowest FFAR decile is 40.1 basis points, which is the highest SoftFee mean across all FFAR deciles (the rank is 10); the mean SoftFee for fund-years in the highest FFAR decile is 26.7 basis points, which is the second highest across all FFAR deciles (the rank is 9). FFAR is the four-factor model alpha (stands for the four-factor adjusted return), in percent, SoftFee is the proportion of total net assets paid as bundled (soft dollar) commissions, in basis points, BrkFee is the proportion of total net assets paid as total brokerage commissions, in basis points, $S D U$ is the ratio of soft dollar commissions to total brokerage commissions (SoftFee/BrkFee), in \%, TNA is the total net assets, Turn is turnover (total sales and purchases divided by total net assets), in decimals, and $A d v F e e$ is the gross advisory fee divided by total net assets, in basis points.

Panel A: All Funds

\begin{tabular}{|c|c|c|c|c|c|c|c|}
\hline Decile Rank & FFAR & SoftFee, bps & BrkFee, bps & SDU, \% & TNA, \$mln & Turn & AdvFee, bps \\
\hline Low FFAR & $-0.254(1)$ & $40.1(10)$ & $81.4(10)$ & $49.4(9)$ & $282(1)$ & $4.51(10)$ & $88.2(10)$ \\
\hline High FFAR & $0.265(10)$ & $26.7(9)$ & $47.2(8)$ & $55.7(10)$ & $767(5)$ & $3.22(7)$ & $77.1(6)$ \\
\hline Difference & $0.519 * * *$ & $-13.4 * *$ & $-34.2 * * *$ & 6.3 & $485^{* * *}$ & $-1.29 * *$ & $-11.1 * * *$ \\
\hline Low SoftFee & $-0.007(5)$ & $0.2(1)$ & $19.6(1)$ & $3.4(1)$ & $897(4)$ & $1.79(1)$ & $73.7(1)$ \\
\hline High SoftFee & $-0.044(1)$ & $94.4(10)$ & $119.5(10)$ & $84.2(10)$ & $305(1)$ & $6.00(10)$ & $93.5(10)$ \\
\hline Difference & $-0.037 *$ & $94.2 * * *$ & $99.9 * * *$ & $80.8 * * *$ & $-593 * * *$ & $4.21 * * *$ & $19.8 * * *$ \\
\hline Low BrkFee & $0.030(10)$ & $1.7(1)$ & $4.3(1)$ & 37.7 (1) & $1,351(2)$ & $1.09(1)$ & $68.2(1)$ \\
\hline High BrkFee & $-0.042(2)$ & $69.3(10)$ & $172.9(10)$ & $42.4(3)$ & $172(10)$ & $11.51(10)$ & $103.7(10)$ \\
\hline Difference & $-0.072 * * *$ & $67.7 * * *$ & $168.6^{* * * *}$ & 4.7 & $-1,179 * * *$ & $10.42 * * *$ & $35.5 * * *$ \\
\hline Low SDU & $-0.036(1)$ & $0.5(1)$ & $47.8(8)$ & $0.9(1)$ & $582(2)$ & $3.23(6)$ & $80.9(8)$ \\
\hline High SDU & $-0.012(4)$ & $39.7(9)$ & $40.4(6)$ & $98.5(10)$ & 799 (8) & $2.42(2)$ & $86.4(10)$ \\
\hline Difference & 0.024 & 39.2 & -7.4 & $97.6 * * *$ & 217 & $-0.80 * *$ & $5.5^{*}$ \\
\hline Low TNA & $-0.035(1)$ & $15.1(5)$ & $42.6(6)$ & $36.0(1)$ & $8(1)$ & $2.80(7)$ & $81.2(4)$ \\
\hline High TNA & $0.022(10)$ & $10.5(1)$ & $17.3(1)$ & $55.4(10)$ & $4,934(10)$ & 1.89 (1) & $59.6(1)$ \\
\hline Difference & $0.058 * * *$ & $-4.6^{*}$ & $-25.3 * * *$ & $19.4 * * *$ & $4,926 * * *$ & $-0.91 * *$ & $-21.6 * * *$ \\
\hline Low Turn & $-0.017(4)$ & $3.0(1)$ & $10.3(1)$ & $34.4(1)$ & $1,175(9)$ & $0.48(1)$ & $68.6(1)$ \\
\hline High Turn & $-0.029(2)$ & $54.2(10)$ & $139.1(10)$ & $40.2(2)$ & $351(2)$ & $13.07(10)$ & $96.1(10)$ \\
\hline Difference & -0.013 & $51.2 * * *$ & $128.8 * * *$ & 5.7 & $-824 * * *$ & $12.60 * * *$ & $27.5 * * *$ \\
\hline Low AdvFee & $0.005(9)$ & $6.7(2)$ & $27.1(2)$ & $35.5(4)$ & $1,918(10)$ & $1.62(1)$ & $39.6(1)$ \\
\hline High AdvFee & $-0.021(4)$ & $38.2(10)$ & $79.2(10)$ & $42.2(5)$ & $177(1)$ & $3.43(8)$ & $135.2(10)$ \\
\hline Difference & -0.026 & $31.5 * * *$ & $52.1 * * *$ & 6.6 & $-1,741 * * *$ & $1.80 * * *$ & $95.7 * * *$ \\
\hline
\end{tabular}


Table 3 (continued)

\begin{tabular}{|c|c|c|c|c|c|c|c|}
\hline Decile Rank & FFAR & SoftFee, bps & BrkFee, bps & SDU, $\%$ & TNA, \$mln & Turn & AdvFee, bps \\
\hline Low FFAR & $-0.239(1)$ & $41.3(10)$ & $80.4(10)$ & $50.3(8)$ & $429(1)$ & $3.80(10)$ & $89.1(10)$ \\
\hline High FFAR & $0.272(10)$ & $20.1(9)$ & $32.0(7)$ & $58.9(10)$ & $1,056(5)$ & $2.68(9)$ & $75.2(6)$ \\
\hline Difference & $0.511 * * *$ & $-21.2 * * *$ & $-48.4 * * *$ & 8.7 & $626 * * *$ & $-1.11 * * *$ & $-13.9 * * *$ \\
\hline Low SoftFee & $0.009(10)$ & $0.1(1)$ & $18.1(2)$ & $3.3(1)$ & 959 (4) & $1.67(1)$ & $69.6(1)$ \\
\hline High SoftFee & $-0.051(1)$ & $92.2(10)$ & $111.7(10)$ & $87.2(10)$ & 417 (1) & 4.77 (10) & $93.6(10)$ \\
\hline Difference & $-0.060 * * *$ & $92.1 * * *$ & $93.6^{* * *}$ & 83.8 & $-542 * * *$ & $3.09 * * *$ & $24.0 * * *$ \\
\hline Low BrkFee & $0.026(10)$ & $1.4(1)$ & $3.7(1)$ & $37.4(1)$ & $1,482(8)$ & $1.04(1)$ & $67.2(1)$ \\
\hline High BrkFee & $-0.053(2)$ & $74.1(10)$ & $137.7(10)$ & $54.3(10)$ & $332(1)$ & $5.91(10)$ & $106.0(10)$ \\
\hline Difference & $-0.079 * * *$ & $72.7 * * *$ & $134.0 * * *$ & $17.0 * * *$ & $-1,150 * * *$ & $4.87 * * *$ & $38.8 * * *$ \\
\hline Low SDU & $-0.039(1)$ & $0.4(1)$ & $38.4(8)$ & $0.8(1)$ & $786(2)$ & $2.79(9)$ & $73.9(5)$ \\
\hline High SDU & $-0.009(3)$ & $39.3(9)$ & $39.9(9)$ & $98.5(10)$ & $1,063(7)$ & $2.41(5)$ & 83.9 (10) \\
\hline Difference & 0.031 & $38.9 * * *$ & 1.6 & $97.7 * * * *$ & 277 & -0.37 & $10.0 * * *$ \\
\hline Low TNA & $-0.035(1)$ & $26.4(10)$ & $54.7(10)$ & $46.3(5)$ & $61(1)$ & $3.53(10)$ & $89.1(10)$ \\
\hline High TNA & $0.039(10)$ & $8.9(1)$ & $15.1(1)$ & $54.6(9)$ & $6,002(10)$ & $1.79(1)$ & $58.6(1)$ \\
\hline Difference & $0.073 * * *$ & $-17.5 * * *$ & $-39.6 * * *$ & 8.2 & $5,941 * * *$ & $-1.74 * * *$ & $-30.5^{* * *}$ \\
\hline Low Turn & $-0.022(3)$ & $2.7(1)$ & $8.3(1)$ & $35.3(1)$ & $1,466(10)$ & $0.45(1)$ & $68.8(1)$ \\
\hline High Turn & $-0.054(1)$ & $57.3(10)$ & $108.3(10)$ & $48.5(7)$ & $608(2)$ & $7.51(10)$ & $97.1(10)$ \\
\hline Difference & $-0.032 *$ & $54.6^{* * *}$ & $100.0 * * *$ & $13.1 * *$ & $-858 * * *$ & $7.05 * * *$ & $28.2 * * *$ \\
\hline Low AdvFee & $0.001(9)$ & $5.7(1)$ & $17.6(1)$ & $38.0(3)$ & $2,098(10)$ & $1.65(1)$ & $39.4(1)$ \\
\hline High AdvFee & $-0.020(4)$ & $42.5(10)$ & $82.1(10)$ & $43.7(5)$ & $276(1)$ & $3.41(10)$ & $133.6(10)$ \\
\hline Difference & -0.021 & $36.8 * * *$ & $64.5^{* * *}$ & 5.6 & $-1,822 * * *$ & $1.75 * * *$ & $94.3 * * *$ \\
\hline
\end{tabular}

$* * *, * *, *$ denote significant difference between decile means at the $1 \%, 5 \%$, and $10 \%$ level, respectively (for a two-tailed t-test assuming equal variances). 
Table 4 Panel Regressions of Risk-adjusted Fund Returns. The dependent variable is the annualized alpha from the Carhart (1997) four-factor model (the four-factor adjusted return, FFAR), in percent. SDU is the ratio of soft dollar commissions to total brokerage commissions (SoftFee/BrkFee), in \%, SoftFee is the proportion of total net assets paid as bundled (soft dollar) commissions, in basis points, BrkFee is the proportion of total net assets paid as total brokerage commissions, in basis points, Turn is turnover (total sales and purchases divided by total net assets), in decimals, TurnCost is the cost of turning over the portfolio once (BrkFee/Turn), in basis points, and FundSize is the average of twelve monthly total net assets figures, in thousands of dollars. Objective and year fixed effects are included. Fund and time subscripts are suppressed except for lagged variables. T-statistics are in square brackets below coefficients.

\begin{tabular}{|c|c|c|c|c|c|c|c|}
\hline \multicolumn{8}{|c|}{ Panel A: All Funds } \\
\hline Variable & $\operatorname{Reg}[1]$ & Reg [2] & $\operatorname{Reg}[3]$ & $\operatorname{Reg}[4]$ & $\operatorname{Reg}[5]$ & $\operatorname{Reg}[6]$ & Reg [7] \\
\hline \multirow[t]{2}{*}{ Intercept } & 1.51 & 2.06 & 5.64 & 1.58 & $8.45 * *$ & 2.17 & $9.64 * *$ \\
\hline & {$[0.34]$} & {$[0.46]$} & {$[1.25]$} & {$[0.35]$} & [1.98] & {$[0.49]$} & {$[2.21]$} \\
\hline \multirow[t]{2}{*}{ SDU } & 0.02 & & & & & & \\
\hline & [1.38] & & & & & & \\
\hline \multirow{2}{*}{ SoftFee } & & $-0.06 * * *$ & & & & $-0.06 * * *$ & \\
\hline & & {$[-2.97]$} & & & & {$[-2.95]$} & \\
\hline \multirow[t]{2}{*}{ BrkFee } & & & $-0.06 * * *$ & & & & \\
\hline & & & {$[-5.28]$} & & & & \\
\hline \multirow[t]{2}{*}{ Turn } & & & & -0.07 & & -0.05 & $-0.25 * * *$ \\
\hline & & & & {$[-0.72]$} & & {$[-0.61]$} & {$[-2.76]$} \\
\hline \multirow[t]{2}{*}{ TurnCost } & & & & & $-0.33 * * *$ & & $-0.35 * * *$ \\
\hline & & & & & {$[-7.67]$} & & {$[-7.96]$} \\
\hline \multirow{2}{*}{$\operatorname{Ln}\left(\right.$ FundSize $\left._{t-1}\right)$} & 0.11 & 0.08 & -0.14 & 0.12 & -0.10 & 0.07 & -0.16 \\
\hline & {$[0.52]$} & {$[0.36]$} & {$[-0.65]$} & {$[0.55]$} & {$[-0.43]$} & {$[0.30]$} & {$[-0.74]$} \\
\hline Obj. FE & Yes & Yes & Yes & Yes & Yes & Yes & Yes \\
\hline Year FE & Yes & Yes & Yes & Yes & Yes & Yes & Yes \\
\hline Adj. $R^{2}$ & $5.7 \%$ & $7.0 \%$ & $9.3 \%$ & $5.4 \%$ & $12.2 \%$ & $6.8 \%$ & $12.6 \%$ \\
\hline F-stat & $5.24 * * *$ & $6.30 * * *$ & $8.23 * * *$ & $4.96 * * *$ & $10.72 * * *$ & $5.77 * * *$ & $10.45^{* * *}$ \\
\hline $\mathrm{N}$ (funds) & 376 & 376 & 376 & 376 & 376 & 376 & 376 \\
\hline $\mathrm{N}$ (fund-yrs.) & 1,159 & 1,159 & 1,159 & 1,156 & 1,156 & 1,156 & 1,156 \\
\hline
\end{tabular}


Table 4 (continued)

\begin{tabular}{|c|c|c|c|c|c|c|c|}
\hline \multicolumn{8}{|c|}{ Panel B: Funds with Net Assets over $\$ 50 \mathrm{mln}$} \\
\hline Variable & $\operatorname{Reg}[1]$ & Reg [2] & $\operatorname{Reg}[3]$ & $\operatorname{Reg}[4]$ & Reg [5] & Reg [6] & Reg [7] \\
\hline Intercept & 7.70 & 8.88 & $15.22 *$ & 8.95 & $16.75 * * *$ & 9.89 & $18.64 * *$ \\
\hline & [0.97] & {$[1.14]$} & [1.89] & {$[1.08]$} & {$[2.77]$} & {$[1.22]$} & {$[2.36]$} \\
\hline SDU & $\begin{array}{l}0.02 \\
{[1.30]}\end{array}$ & & & & & & \\
\hline SoftFee & & $\begin{array}{l}-0.06 * * * \\
{[-2.60]}\end{array}$ & & & & $\begin{array}{l}-0.05 * * * \\
{[-2.82]}\end{array}$ & \\
\hline BrkFee & & & $\begin{array}{l}-0.08 * * * \\
{[-5.95]}\end{array}$ & & & & \\
\hline Turn & & & & $\begin{array}{l}-0.68 * \\
{[-1.87]}\end{array}$ & & $\begin{array}{l}-0.52 * \\
{[-1.67]}\end{array}$ & $\begin{array}{l}-0.69 * * \\
{[-2.49]}\end{array}$ \\
\hline TurnCost & & & & & $\begin{array}{l}-0.37 * * * \\
{[-6.76]}\end{array}$ & & $\begin{array}{l}-0.37 * * * \\
{[-6.90]}\end{array}$ \\
\hline $\operatorname{Ln}\left(\right.$ FundSize $\left._{t-1}\right)$ & $\begin{array}{l}-0.36 \\
{[-0.94]}\end{array}$ & $\begin{array}{l}-0.44 \\
{[-1.17]}\end{array}$ & $\begin{array}{l}-0.81 * * \\
{[-2.20]}\end{array}$ & $\begin{array}{l}-0.36 \\
{[-0.96]}\end{array}$ & $\begin{array}{l}-0.68 * \\
{[-1.86]}\end{array}$ & $\begin{array}{l}-0.46 \\
{[-1.24]}\end{array}$ & $\begin{array}{l}-0.75 * * \\
{[-2.04]}\end{array}$ \\
\hline Obj. FE & Yes & Yes & Yes & Yes & Yes & Yes & Yes \\
\hline Year FE & Yes & Yes & Yes & Yes & Yes & Yes & Yes \\
\hline Adj. $R^{2}$ & $8.0 \%$ & $9.3 \%$ & $13.4 \%$ & $8.2 \%$ & $14.9 \%$ & $9.3 \%$ & $15.6 \%$ \\
\hline F-stat & $5.55 * * *$ & $6.34 * * *$ & $9.13^{* * *}$ & $5.68 * * *$ & $10.17 * * *$ & $6.01 * * *$ & $10.04 * * *$ \\
\hline $\mathrm{N}$ (funds) & 284 & 284 & 284 & 284 & 284 & 284 & 284 \\
\hline $\mathrm{N}$ (fund-years) & 865 & 864 & 864 & 864 & 864 & 864 & 864 \\
\hline
\end{tabular}

***, $* *, *$ denote significance at the $1 \%, 5 \%$, and $10 \%$ level, respectively. 
Table 5 Panel Regressions of Advisory Fee. The dependent variable is AdvFee, the gross advisory fee divided by fund size, in basis points. $S D U$ is the ratio of soft dollar commissions to total brokerage commissions (SoftFee/BrkFee), in \%, SoftFee is the proportion of assets paid as soft dollar commission, in basis points, BrkFee is the proportion of total net assets paid as total brokerage commissions, in basis points, Turn is fund turnover in decimals, TurnCost is the cost of turning over the portfolio once (BrkFee/Turn), in basis points, FundSize is the average of twelve monthly total net assets figures, in thousands of dollars, AdvSize is the adviser size (assets under management in \$ million), Accts is the number of shareholder accounts with the adviser, in thousands, Reimb is the reimbursement from the fund to the shareholders divided by the total net assets, in basis points, ObjConcntr is concentration of funds in a given investment objective measured by the normalized Herfindahl index. The last five variables are related to fund governance: Indep is the percentage of independent directors on the board, Seats is the number of seats on the board, MedTenure is the median tenure of fund directors, in years, Fin is the percentage of fund directors with finance background, OtherDir is the percentage of the board directors who have at least one directorship outside of the fund family, and Compens $_{t-1}$ is the average compensation of the fund directors lagged one year, in $\$$ thousand. Objective and year fixed effects are included. Fund and time subscripts are suppressed except for lagged variables. T-statistics are in square brackets below coefficients. 


\begin{tabular}{|c|c|c|c|c|c|c|c|}
\hline \multicolumn{8}{|l|}{ Panel A: All Funds } \\
\hline Variable & $\operatorname{Reg}[1]$ & $\operatorname{Reg}[2]$ & Reg [3] & Reg [4] & $\operatorname{Reg}[5]$ & Reg [6] & Reg [7] \\
\hline \multirow[t]{2}{*}{ Intercept } & $108.95^{* * *}$ & $105.42 * * *$ & $101.22 * * *$ & $107.11 * * *$ & $119.96 * * *$ & $103.25 * * *$ & $116.87 * * *$ \\
\hline & {$[8.95]$} & {$[8.91]$} & {$[8.73]$} & {$[8.65]$} & {$[10.53]$} & {$[8.66]$} & {$[10.12]$} \\
\hline \multirow[t]{2}{*}{ SDU } & $0.04 *$ & & & & & & \\
\hline & [1.87] & & & & & & \\
\hline \multirow[t]{2}{*}{ SoftFee } & & $0.11 * * *$ & & & & $0.11 * * *$ & \\
\hline & & {$[5.14]$} & & & & {$[4.80]$} & \\
\hline \multirow[t]{2}{*}{ BrkFee } & & & $0.07 * * *$ & & & & \\
\hline & & & {$[3.63]$} & & & & \\
\hline \multirow[t]{2}{*}{ Turn } & & & & $0.47 * * *$ & & $0.35^{* *}$ & $0.38 * *$ \\
\hline & & & & [3.13] & & {$[2.35]$} & [2.49] \\
\hline \multirow[t]{2}{*}{ TurnCost } & & & & & $-0.20 * *$ & & $-0.18 * *$ \\
\hline & & & & & {$[-2.17]$} & & {$[-1.98]$} \\
\hline \multirow[t]{2}{*}{ Ln(FundSize $)$} & $-3.22 * * *$ & $-2.86 * * *$ & $-2.62 * * *$ & $-3.12 * * *$ & $-3.68 * * *$ & $-2.75 * * *$ & $-3.51 * * *$ \\
\hline & {$[-4.36]$} & {$[-4.00]$} & {$[-3.67]$} & {$[-4.11]$} & {$[-5.17]$} & {$[-3.82]$} & {$[-4.89]$} \\
\hline \multirow[t]{2}{*}{ Ln(AdvSize) } & -0.30 & -0.44 & -0.51 & -0.42 & -0.64 & -0.53 & -0.72 \\
\hline & $[-0.50]]$ & {$[-0.76]$} & {$[-0.86]$} & {$[-0.68]$} & {$[-1.05]$} & {$[-0.89]$} & {$[-1.19]$} \\
\hline \multirow[t]{2}{*}{$\operatorname{Ln}$ (Accounts) } & $0.80 * * *$ & $0.77 * * *$ & $0.81 * * *$ & $0.88 * * *$ & $0.97 * * *$ & $0.80 * * *$ & $1.00 * * *$ \\
\hline & [3.03] & {$[2.94]$} & {$[3.17]$} & {$[3.34]$} & {$[3.58]$} & {$[3.03]$} & [3.69] \\
\hline \multirow[t]{2}{*}{ Reimb } & 0.01 & 0.01 & 0.02 & 0.02 & 0.02 & 0.01 & 0.02 \\
\hline & [1.10] & [1.07] & [1.02] & {$[1.22]$} & [1.36] & [1.12] & {$[1.40]$} \\
\hline \multirow[t]{2}{*}{ ObjConcntr } & $0.12 *$ & 0.11 & $0.14 * *$ & $0.15^{* *}$ & $0.13^{*}$ & $0.12 *$ & $0.15^{* *}$ \\
\hline & [1.81] & [1.54] & [2.06] & [2.17] & [1.94] & [1.79] & [2.19] \\
\hline \multirow[t]{2}{*}{ Indep } & 0.08 & 0.09 & 0.07 & 0.06 & 0.06 & 0.08 & 0.05 \\
\hline & [0.93] & [1.10] & {$[0.83]$} & [0.67] & {$[0.76]$} & [0.97] & {$[0.64]$} \\
\hline \multirow[t]{2}{*}{ Seats } & $-0.91 * * *$ & $-0.83 * * *$ & $-0.84 * * *$ & $-0.74 * * *$ & $-0.86^{* * *}$ & $-0.77 * * *$ & $-0.79 * * *$ \\
\hline & {$[-3.63]$} & {$[-3.62]$} & {$[-3.73]$} & {$[-3.20]$} & {$[-3.56]$} & {$[-3.30]$} & {$[-3.23]$} \\
\hline \multirow{2}{*}{ MedTenure } & 0.01 & 0.08 & 0.05 & 0.03 & -0.04 & 0.10 & -0.02 \\
\hline & {$[0.11]$} & [0.67] & [0.37] & {$[0.26]$} & {$[-0.27]$} & {$[0.76]$} & {$[-0.12]$} \\
\hline \multirow[t]{2}{*}{ Fin } & $0.14 * *$ & $0.12 *$ & $0.13^{*}$ & $0.16^{* *}$ & $0.15^{* *}$ & $0.12 *$ & $0.15^{* *}$ \\
\hline & [1.97] & [1.71] & [1.79] & [2.17] & [2.09] & [1.81] & [2.17] \\
\hline \multirow[t]{2}{*}{ OtherDir } & -0.03 & -0.02 & -0.02 & -0.02 & -0.03 & -0.01 & -0.01 \\
\hline & [-1.09] & {$[-0.74]$} & {$[-0.42]$} & {$[-0.53]$} & {$[-0.83]$} & {$[-0.33]$} & {$[-0.35]$} \\
\hline \multirow[t]{2}{*}{ Compens $_{\mathrm{t}-1}$} & $-0.05 * * *$ & $-0.05 * * *$ & $-0.04 * *$ & $-0.04 * *$ & $-0.04 * *$ & $-0.05^{* *}$ & $-0.04 * *$ \\
\hline & {$[-2.67]$} & {$[-2.83]$} & {$[-2.35]$} & {$[-2.38]$} & {$[-2.47]$} & {$[-2.44]$} & {$[-2.50]$} \\
\hline Obj. fixed effects & Yes & Yes & Yes & Yes & Yes & Yes & Yes \\
\hline Year fixed effects & Yes & Yes & Yes & Yes & Yes & Yes & Yes \\
\hline Adj. $R^{2}$ & $8.4 \%$ & $10.7 \%$ & $10.6 \%$ & $8.4 \%$ & $9.8 \%$ & $11.0 \%$ & $10.1 \%$ \\
\hline F-stat & $6.02 * * *$ & $7.55^{* * *}$ & $7.49 * * *$ & $5.98 * * *$ & $6.91 * * *$ & $7.47 * * *$ & $6.88 * * *$ \\
\hline $\mathrm{N}$ (funds) & 370 & 370 & 370 & 370 & 370 & 370 & 370 \\
\hline $\mathrm{N}$ (fund-yrs.) & 1,421 & 1,421 & 1,421 & 1,418 & 1,418 & 1,418 & 1,418 \\
\hline
\end{tabular}


Table 5 (continued)

\begin{tabular}{|c|c|c|c|c|c|c|c|}
\hline \multicolumn{8}{|c|}{ Panel B: Funds with Net Assets over $\$ 50 \mathrm{mln}$} \\
\hline Variable & $\operatorname{Reg}[1]$ & $\operatorname{Reg}[2]$ & $\operatorname{Reg}[3]$ & Reg [4] & $\operatorname{Reg}[5]$ & Reg [6] & Reg [7] \\
\hline \multirow[t]{2}{*}{ Intercept } & $135.55 * * *$ & $128.58 * * *$ & $122.13 * * *$ & $131.46^{* * *}$ & $144.18 * * *$ & $125.04 * * *$ & $139.17 * * *$ \\
\hline & {$[8.90]$} & {$[8.80]$} & [8.86] & [8.83] & {$[10.42]$} & {$[8.62]$} & {$[10.13]$} \\
\hline \multirow[t]{2}{*}{ SDU } & 0.01 & & & & & & \\
\hline & {$[0.67]$} & & & & & & \\
\hline \multirow[t]{2}{*}{ SoftFee } & & $0.11 * * *$ & & & & $0.11 * * *$ & \\
\hline & & {$[4.86]$} & & & & [4.66] & \\
\hline \multirow[t]{2}{*}{ BrkFee } & & & $0.11 * * *$ & & & & \\
\hline & & & [4.96] & & & & \\
\hline \multirow[t]{2}{*}{ Turn } & & & & $0.78 * *$ & & $0.68 * *$ & $0.79 * *$ \\
\hline & & & & [2.21] & & [1.98] & [2.13] \\
\hline \multirow[t]{2}{*}{ TurnCost } & & & & & -0.10 & & -0.08 \\
\hline & & & & & {$[-0.95]$} & & {$[-0.81]$} \\
\hline \multirow[t]{2}{*}{ Ln(FundSize) } & $-5.02 * * *$ & $-4.41 * * *$ & $-4.06^{* * *}$ & $-4.76 * * *$ & $-5.40 * * *$ & $-4.20 * * *$ & $-5.09 * * *$ \\
\hline & {$[-5.41]$} & {$[-4.96]$} & {$[-4.67]$} & {$[-5.07]$} & {$[-6.00]$} & {$[-4.66]$} & {$[-5.56]$} \\
\hline \multirow[t]{2}{*}{ Ln(AdvSize $)$} & -0.02 & -0.14 & -0.21 & -0.09 & -0.24 & -0.22 & -0.33 \\
\hline & {$[-0.03]$} & {$[-0.19]$} & {$[-0.29]$} & {$[-0.12]$} & {$[-0.32]$} & {$[-0.29]$} & {$[-0.45]$} \\
\hline \multirow[t]{2}{*}{ Ln(Accounts) } & $1.12 * * *$ & $1.05^{* * *}$ & $1.08 * * *$ & $1.11 * * *$ & $1.23 * * *$ & $1.04 * * *$ & $1.22 * * *$ \\
\hline & {$[3.05]$} & [2.94] & [3.11] & [3.04] & {$[3.34]$} & [2.93] & [3.32] \\
\hline \multirow[t]{2}{*}{ Reimb } & 0.02 & 0.01 & 0.01 & 0.02 & 0.02 & 0.01 & 0.03 \\
\hline & {$[0.78]$} & {$[0.44]$} & {$[0.56]$} & {$[0.88]$} & {$[1.00]$} & {$[0.57]$} & [1.08] \\
\hline \multirow[t]{2}{*}{ ObjConcntr } & 0.04 & 0.02 & 0.04 & 0.05 & 0.04 & 0.03 & 0.05 \\
\hline & {$[0.58]$} & [0.29] & {$[0.61]$} & {$[0.74]$} & {$[0.55]$} & {$[0.45]$} & {$[0.71]$} \\
\hline \multirow[t]{2}{*}{ Indep } & 0.01 & 0.03 & 0.02 & 0.00 & 0.00 & 0.02 & 0.00 \\
\hline & {$[0.12]$} & {$[0.34]$} & {$[0.22]$} & {$[0.00]$} & {$[0.04]$} & {$[0.26]$} & {$[0.03]$} \\
\hline \multirow[t]{2}{*}{ Seats } & $-0.84 * * *$ & $-0.86^{* * *}$ & $-0.91 * * *$ & $-0.77 * * *$ & $-0.94 * * *$ & $-0.81 * * *$ & $-0.89 * * *$ \\
\hline & {$[-3.42]$} & {$[-3.53]$} & {$[-3.82]$} & {$[-3.19]$} & {$[-3.68]$} & {$[-3.36]$} & {$[-3.50]$} \\
\hline \multirow[t]{2}{*}{ MedTenure } & -0.01 & 0.04 & 0.04 & 0.02 & -0.04 & 0.06 & 0.02 \\
\hline & {$[-0.05]$} & {$[0.33]$} & {$[0.30]$} & {$[0.12]$} & {$[-0.29]$} & {$[0.45]$} & {$[0.13]$} \\
\hline \multirow[t]{2}{*}{ Fin } & $0.16^{* *}$ & $0.14 * *$ & $0.12 *$ & $0.16^{* *}$ & $0.16^{* *}$ & $0.14 * *$ & $0.16 * *$ \\
\hline & {$[2.25]$} & {$[2.08]$} & {$[1.81]$} & {$[2.28]$} & {$[2.27]$} & [2.12] & {$[2.30]$} \\
\hline \multirow[t]{2}{*}{ OtherDir } & -0.01 & -0.01 & 0.01 & -0.00 & -0.01 & 0.00 & 0.01 \\
\hline & {$[-0.34]$} & {$[-0.18]$} & [0.19] & {$[-0.06]$} & {$[-0.16]$} & {$[0.07]$} & {$[0.16]$} \\
\hline \multirow{2}{*}{ Compens $_{\mathrm{t}-1}$} & $-0.05 * * *$ & $-0.05^{* * *}$ & $-0.05^{* * *}$ & $-0.05 * * *$ & $-0.05 * * *$ & $-0.05 * * *$ & $-0.05 * * *$ \\
\hline & {$[-2.87]$} & {$[-3.13]$} & {$[-2.77]$} & {$[-2.81]$} & {$[-2.76]$} & {$[-3.09]$} & {$[-2.73]$} \\
\hline Obj. fixed effects & Yes & Yes & Yes & Yes & Yes & Yes & Yes \\
\hline Year fixed effects & Yes & Yes & Yes & Yes & Yes & Yes & Yes \\
\hline Adj. $R^{2}$ & $9.3 \%$ & $12.0 \%$ & $14.1 \%$ & $9.6 \%$ & $10.6 \%$ & $12.3 \%$ & $11.2 \%$ \\
\hline F-stat & $5.14 * * *$ & $6.55 * * *$ & $7.65 * * *$ & $5.29 * * *$ & $5.83 * * *$ & $6.51 * * *$ & $5.95^{* * *}$ \\
\hline $\mathrm{N}$ (funds) & 294 & 294 & 294 & 294 & 294 & 294 & 294 \\
\hline $\mathrm{N}$ (fund-yrs.) & 1,057 & 1,057 & 1,057 & 1,057 & 1,057 & 1,057 & 1,057 \\
\hline
\end{tabular}

$* * *, * *, *$ denote significance at the $1 \%, 5 \%$, and $10 \%$ level, respectively. 
Table 6 Panel Regressions of Cost of Investing Measures. The dependent variable is one of the following: $S D U$ - the ratio of soft dollar commissions to total brokerage commissions (SoftFee/BrkFee), in \%, SoftFee - the proportion of assets paid as soft dollar commission, in basis points, BrkFee - the proportion of total net assets paid as total brokerage commissions, in basis points, Turn - fund turnover in decimals, or TurnCost - the cost of turning over the portfolio once (BrkFee/Turn), in basis points. The independent variables which do not serve as dependent variables in different versions of the regression are: Researcha dummy variable equal to one if receipt of investment research and statistical information is a consideration for broker participation, Sales - a dummy variable equal to one if sales of fund's shares is a consideration for broker participation, AltComp - the proportion of total net assets received by brokers or dealers as part of total front-end load and 12b-1 fee, in basis points, BrConcntr - the fund's brokerage service concentration measured by Herfindahl index, Aff - a dummy variable equal to one if any broker or dealer is affiliated with the adviser, Cred-a dummy variable equal to one if there is an arrangement to return or credit part of total commissions or profits by at least one broker to the fund adviser, FundSize the average of twelve monthly total net assets figures, in thousands of dollars, AdvSize is the adviser size (assets under management in \$ million), Accts is the number of shareholder accounts with the adviser, in thousands, Reimb is the reimbursement from the fund to the shareholders divided by the total net assets, in basis points, ObjConcntr is concentration of funds in a given investment objective measured by the normalized Herfindahl index. The last five independent variables are related to fund governance: Indep is the percentage of independent directors on the board, Seats is the number of seats on the board, MedTenure is the median tenure of fund directors, in years, Fin is the percentage of fund directors with finance background, OtherDir is the percentage of the board directors who have at least one directorship outside of the fund family, and Compens $s_{t-1}$ is the average compensation of the fund directors lagged one year, in thousands of dollars. Objective and year fixed effects are included. Fund and time subscripts are suppressed except for lagged variables. T-statistics are in square brackets below coefficients. 


\begin{tabular}{|c|c|c|c|c|c|}
\hline \multicolumn{6}{|l|}{ Panel A: All Funds } \\
\hline Variable & SDU & SoftFee & BrkFee & Turn & TurnCost \\
\hline \multirow[t]{2}{*}{ Intercept } & 7.01 & 23.92 & $82.37 * * *$ & $5.40 * * *$ & $32.97 * * *$ \\
\hline & {$[0.76]$} & {$[1.33]$} & {$[3.67]$} & {$[4.83]$} & [7.38] \\
\hline \multirow[t]{2}{*}{ Research } & 2.09 & 1.91 & 1.50 & $-2.01 * * *$ & -1.23 \\
\hline & {$[0.75]$} & {$[0.67]$} & {$[0.62]$} & {$[-4.23]$} & {$[-0.73]$} \\
\hline \multirow{2}{*}{ Sales } & 3.90 & -0.62 & 2.62 & $0.23 * *$ & -0.07 \\
\hline & {$[1.54]$} & {$[-0.25]$} & {$[0.75]$} & {$[2.02]$} & {$[-0.23]$} \\
\hline \multirow[t]{2}{*}{ AltComp } & 0.03 & $0.06^{*}$ & $0.06^{*}$ & -0.00 & -0.00 \\
\hline & {$[0.86]$} & [1.91] & {$[1.82]$} & {$[-0.22]$} & {$[-0.46]$} \\
\hline \multirow[t]{2}{*}{ BrConcntr } & 0.07 & -0.03 & $-0.10 * *$ & 0.00 & -0.04 \\
\hline & [1.29] & {$[-0.88]$} & {$[-2.35]$} & {$[0.48]$} & {$[-1.02]$} \\
\hline \multirow[t]{2}{*}{ Aff } & 1.13 & 1.09 & -4.46 & -0.30 & $-1.73 *$ \\
\hline & {$[0.72]$} & {$[0.58]$} & {$[-1.45]$} & {$[-0.33]$} & {$[-1.87]$} \\
\hline \multirow[t]{2}{*}{ Cred } & 0.58 & -0.76 & 6.77 & -0.06 & -0.79 \\
\hline & {$[0.64]$} & {$[-0.30]$} & {$[1.48]$} & {$[-0.53]$} & {$[-0.46]$} \\
\hline \multirow[t]{2}{*}{ Ln(FundSize) } & -0.07 & $-2.40 * * *$ & $-6.16^{* * *}$ & -0.13 & $-1.30 * * *$ \\
\hline & {$[-0.25]$} & {$[-2.67]$} & {$[-4.55]$} & {$[-1.38]$} & {$[-6.04]$} \\
\hline \multirow{2}{*}{ Ln(AdvSize) } & $-1.60 *$ & 0.29 & -0.59 & $-0.11^{*}$ & $-0.86 * * *$ \\
\hline & {$[-1.75]$} & {$[0.43]$} & {$[-0.24]$} & {$[-1.78]$} & {$[-2.92]$} \\
\hline \multirow[t]{2}{*}{ Ln(Accounts) } & $1.03 * * *$ & $1.03 * * *$ & 1.60 & $-0.08 * *$ & $0.51 * * *$ \\
\hline & [2.84] & [2.66] & [1.35] & {$[-1.98]$} & [3.73] \\
\hline \multirow[t]{2}{*}{ Reimb } & $0.03 *$ & $0.04 *$ & $0.03 * *$ & -0.00 & 0.06 \\
\hline & [1.76] & [1.82] & [2.09] & {$[-0.79]$} & {$[0.70]$} \\
\hline \multirow[t]{2}{*}{ ObjConcntr } & $0.20^{*}$ & $0.23 *$ & -0.00 & -0.00 & 0.04 \\
\hline & [1.84] & [1.86] & {$[-0.18]$} & {$[-0.47]$} & [1.56] \\
\hline \multirow[t]{2}{*}{ Turn } & $-0.80 * * *$ & $0.99 * *$ & $6.68 * * *$ & & $-0.50 * * *$ \\
\hline & {$[-3.31]$} & {$[2.52]$} & [9.57] & & {$[-4.95]$} \\
\hline \multirow[t]{2}{*}{ Indep } & $-0.15^{*}$ & $-0.17 *$ & -0.19 & $0.01 * *$ & $-0.08 * * *$ \\
\hline & [-1.95] & {$[-1.84]$} & {$[-1.00]$} & [2.15] & {$[-2.84]$} \\
\hline \multirow[t]{2}{*}{ Seats } & 0.06 & -0.31 & 0.13 & $-0.10 * * *$ & -0.09 \\
\hline & [0.18] & {$[-0.87]$} & {$[0.72]$} & {$[-4.10]$} & {$[-0.69]$} \\
\hline \multirow[t]{2}{*}{ MedTenure } & -0.02 & $-0.67 * * *$ & -0.28 & $-0.06^{* * *}$ & $-0.15^{* *}$ \\
\hline & {$[-0.33]$} & {$[-3.58]$} & {$[-1.11]$} & {$[-3.44]$} & {$[2.44]$} \\
\hline \multirow[t]{2}{*}{ Fin } & $0.16^{* *}$ & $0.21 * * *$ & $0.34 * * *$ & -0.08 & $0.09 * * *$ \\
\hline & [2.30] & {$[2.70]$} & [2.86] & {$[-1.55]$} & [2.97] \\
\hline \multirow[t]{2}{*}{ OtherDir } & 0.08 & 0.01 & -0.01 & $-0.02 * * *$ & -0.00 \\
\hline & [1.18] & {$[0.24]$} & {$[-0.22]$} & {$[-3.59]$} & {$[-0.51]$} \\
\hline \multirow[t]{2}{*}{ Compens $_{\mathrm{t}-1}$} & $0.11 * * *$ & $0.05 * *$ & -0.01 & $-0.01 * * *$ & 0.01 \\
\hline & [4.19] & [2.08] & {$[-0.33]$} & {$[-3.28]$} & {$[0.30]$} \\
\hline Obj. fixed effects & Yes & Yes & Yes & Yes & Yes \\
\hline Year fixed effects & Yes & Yes & Yes & Yes & Yes \\
\hline Adj. $\mathrm{R}^{2}$ & $11.6 \%$ & $9.3 \%$ & $33.8 \%$ & $23.6 \%$ & $31.3 \%$ \\
\hline F-stat & $6.52 * * *$ & $5.31 * * *$ & $22.53 * * *$ & $14.43 * * *$ & $20.24 * * *$ \\
\hline $\mathrm{N}$ (funds) & 362 & 362 & 362 & 362 & 362 \\
\hline $\mathrm{N}$ (fund-years) & 1,349 & 1,349 & 1,349 & 1,349 & 1,349 \\
\hline
\end{tabular}


Table 6 (continued)

\begin{tabular}{|c|c|c|c|c|c|}
\hline \multicolumn{6}{|c|}{ Panel B: Funds with Net Assets over $\$ 50 \mathrm{mln}$} \\
\hline Variable & SDU & SoftFee & BrkFee & Turn & TurnCost \\
\hline \multirow[t]{2}{*}{ Intercept } & $57.76 * * *$ & $64.75^{* * *}$ & $98.13 * * *$ & $4.27 * * *$ & $36.74 * * *$ \\
\hline & [3.98] & {$[4.25]$} & {$[3.92]$} & {$[3.04]$} & {$[6.56]$} \\
\hline \multirow[t]{2}{*}{ Research } & 1.34 & 1.32 & 3.42 & $-0.78 * *$ & -0.68 \\
\hline & {$[0.09]$} & {$[0.45]$} & {$[0.83]$} & {$[-2.33]$} & {$[-0.29]$} \\
\hline \multirow[t]{2}{*}{ Sales } & $5.64 * *$ & -1.25 & -1.38 & 0.05 & -0.58 \\
\hline & [1.97] & {$[-0.53]$} & {$[-0.48]$} & {$[0.32]$} & {$[-0.55]$} \\
\hline \multirow[t]{2}{*}{ AltComp } & 0.02 & 0.04 & 0.04 & 0.00 & -0.00 \\
\hline & [0.29] & [0.29] & {$[0.75]$} & {$[0.15]$} & {$[-1.23]$} \\
\hline \multirow[t]{2}{*}{ BrConcntr } & -0.05 & -0.03 & -0.09 & 0.02 & -0.04 \\
\hline & {$[-1.29]$} & {$[-1.59]$} & {$[-1.38]$} & [1.01] & {$[-1.48]$} \\
\hline \multirow{2}{*}{ Aff } & -2.13 & -1.99 & $-5.78 *$ & -0.15 & -1.61 \\
\hline & {$[-0.74]$} & {$[-0.70]$} & {$[-1.86]$} & {$[-0.49]$} & {$[-1.46]$} \\
\hline \multirow[t]{2}{*}{ Cred } & 3.31 & 0.01 & 7.13 & 0.08 & -1.59 \\
\hline & [1.33] & {$[0.30]$} & [1.52] & [1.05] & {$[-1.41]$} \\
\hline \multirow{2}{*}{ Ln(FundSize $)$} & $-3.60 *$ & $-5.37 * * *$ & $-7.27 * * *$ & $-0.27 *$ & $-1.83 * * *$ \\
\hline & {$[-1.80]$} & {$[-5.67]$} & {$[-4.87]$} & {$[-1.79]$} & {$[-5.65]$} \\
\hline \multirow[t]{2}{*}{ Ln(AdvSize $)$} & -1.30 & -0.25 & -0.16 & 0.08 & $-0.56 * * *$ \\
\hline & {$[-0.94]$} & {$[-0.61]$} & {$[-0.29]$} & [1.27] & {$[-2.62]$} \\
\hline \multirow{2}{*}{ Ln(Accounts) } & $1.58 * * *$ & $1.26 * * *$ & 1.11 & 0.02 & $0.59 * * *$ \\
\hline & [3.32] & {$[3.14]$} & [1.23] & {$[0.90]$} & {$[3.48]$} \\
\hline \multirow[t]{2}{*}{ Reimb } & -0.02 & $0.06^{*}$ & $0.09 *$ & -0.01 & -0.00 \\
\hline & {$[-0.54]$} & [1.91] & [1.77] & {$[-1.32]$} & {$[-0.35]$} \\
\hline \multirow[t]{2}{*}{ ObjConcntr } & 0.10 & 0.22 & 0.06 & -0.00 & 0.02 \\
\hline & {$[0.46]$} & [1.52] & {$[0.45]$} & {$[-1.24]$} & {$[0.91]$} \\
\hline \multirow[t]{2}{*}{ Turn } & $-1.07 * *$ & 1.05 & $5.84 * * *$ & & $-0.43^{* *}$ \\
\hline & {$[-2.11]$} & {$[1.44]$} & [3.96] & & {$[-1.99]$} \\
\hline \multirow{2}{*}{ Indep } & $-0.26 * * *$ & $-0.21 * *$ & $-0.20^{*}$ & 0.01 & $-0.07 * *$ \\
\hline & {$[-2.90]$} & {$[-2.06]$} & {$[-1.80]$} & {$[1.55]$} & {$[-2.16]$} \\
\hline \multirow[t]{2}{*}{ Seats } & 0.01 & -0.30 & 0.13 & $-0.05 * *$ & -0.17 \\
\hline & {$[0.05]$} & {$[-0.68]$} & {$[0.48]$} & {$[-2.17]$} & {$[-0.12]$} \\
\hline \multirow[t]{2}{*}{ MedTenure } & -0.01 & $-0.51 * * *$ & -0.30 & $-0.03 * *$ & -0.10 \\
\hline & {$[-0.17]$} & {$[-3.15]$} & {$[-1.26]$} & {$[-2.02]$} & {$[-1.47]$} \\
\hline \multirow[t]{2}{*}{ Fin } & 0.11 & $0.16^{* *}$ & $0.33 * * *$ & -0.00 & $0.08 * * *$ \\
\hline & [1.49] & [2.17] & {$[2.74]$} & {$[-0.05]$} & {$[2.70]$} \\
\hline \multirow[t]{2}{*}{ OtherDir } & $0.13 * *$ & 0.03 & -0.05 & $-0.01 * * *$ & -0.00 \\
\hline & [2.28] & {$[0.75]$} & {$[-0.58]$} & {$[-2.74]$} & {$[-0.39]$} \\
\hline \multirow[t]{2}{*}{ Compens $_{\mathrm{t}-1}$} & $0.08 * *$ & $0.04 *$ & 0.00 & $-0.00 * *$ & 0.01 \\
\hline & [2.19] & {$[1.80]$} & {$[0.68]$} & {$[-1.97]$} & {$[0.45]$} \\
\hline Obj. fixed effects & Yes & Yes & Yes & Yes & Yes \\
\hline Year fixed effects & Yes & Yes & Yes & Yes & Yes \\
\hline Adj. $\mathrm{R}^{2}$ & $13.0 \%$ & $12.0 \%$ & $25.3 \%$ & $7.1 \%$ & $32.7 \%$ \\
\hline F-stat & $5.67 * * *$ & $5.25 * * *$ & $11.58 * * *$ & $3.47 * * *$ & $16.14^{* * *}$ \\
\hline $\mathrm{N}$ (funds) & 286 & 286 & 286 & 286 & 286 \\
\hline $\mathrm{N}$ (fund-years) & 1,000 & 1,000 & 1,000 & 1,000 & 1,000 \\
\hline
\end{tabular}

$* * *, * *, *$ denote significance at the $1 \%, 5 \%$, and $10 \%$ level, respectively. 